\title{
Integration of Solar Process Heat in Industries: A Review
}

\author{
Nahin Tasmin ${ }^{1}{ }^{(}$, Shahjadi Hisan Farjana ${ }^{2}$, Md Rashed Hossain ${ }^{1}$, Santu Golder ${ }^{1}$ and M. A. Parvez Mahmud ${ }^{3, *(D)}$ \\ 1 Department of Mechanical Engineering, Rajshahi University of Engineering \& Technology, Kazla, \\ Rajshahi 6206, Bangladesh; nahinarchi09@gmail.com (N.T.); mrhdeepro@gmail.com (M.R.H.); \\ santu.golder@jacks.sdstate.edu (S.G.) \\ 2 Department of Mechanical Engineering, University of Melbourne, Parkville, VIC 3010, Australia; \\ sfarjana@unimelb.edu.au \\ 3 School of Engineering, Deakin University, Geelong, VIC 3216, Australia \\ * Correspondence: m.a.mahmud@deakin.edu.au
}

\section{check for}

updates

Citation: Tasmin, N.; Farjana, S.H.; Hossain, M.R.; Golder, S.; Mahmud, M.A.P. Integration of Solar Process Heat in Industries: A Review. Clean Technol. 2022, 4, 97-131.

https://doi.org/10.3390/

cleantechnol4010008

Academic Editors: M. Dolores Esteban, José-Santos López-Gutiérrez, Vicente Negro, Ana FernándezGuillamón and Yong Wan

Received: 29 December 2021

Accepted: 14 February 2022

Published: 17 February 2022

Publisher's Note: MDPI stays neutral with regard to jurisdictional claims in published maps and institutional affiliations.

Copyright: (C) 2022 by the authors. Licensee MDPI, Basel, Switzerland. This article is an open access article distributed under the terms and conditions of the Creative Commons Attribution (CC BY) license (https:// creativecommons.org/licenses/by/ $4.0 /)$.

\begin{abstract}
Industrial manufacturing approaches are associated with processing materials that consume a significant amount of thermal energy, termed as industrial process heat. Industrial sectors consume a substantial amount of energy for process heating over a wide range of temperatures (up to $400{ }^{\circ} \mathrm{C}$ ) from agriculture, HVAC to power plants. However, the intensive industrial application of fossil fuels causes unfavorable environmental effects that cannot be ignored. To address this issue, green energy sources have manifested their potential as economical and pollution-free energy sources. Nevertheless, the adoption of solar industrial process heating systems is still limited due to a lack of knowledge in the design/installation aspects, reluctance to experience the technical/infrastructural changes, low price of fossil fuels, and lack of relative incentives. For successful solar process heat integration in industries, a proper understanding of the associated design factors is essential. This paper comprehensively reviews the integration strategies of solar industrial process heating systems, appraisal of the integration points, different aspects of solar collectors, installed thermal power, and thermal storage volume covering case studies, reports and reviews. The integration aspects of solar process heat, findings, and obstacles of several projects from the literature are also highlighted. Finally, the integration locations of SHIP systems are compared for different industrial sectors to find out the most used integration point for a certain sector and operation. It was found that for the food, beverage, and agriculture sector, $51 \%$ of solar process heat integration occurs at the supply level and $27.3 \%$ at the process-level.
\end{abstract}

Keywords: solar industrial process heat; solar collectors; integration layouts; SHIP plants; heat storage systems

\section{Introduction}

Industrial process heat refers to the thermal energy used for the treatment or preparation of substances to process manufactured products [1]. To date, the most widely used thermal energy sources in industries are fossil fuels (coal, petroleum, oil, natural gas, etc.). However, two weighty concerns evolving from the conventional fuel-based industrial processes are global warming and the limited sources of fossil fuels. Reckoning the adverse effects of conventional energy sources on the environment, there is already a growing tendency to introduce renewable energy in industrial process systems from developed to developing countries. According to the latest report of Solar Heat Worldwide, the total number of SHIP projects around the world by the end of 2020 was around 891 with a total installed collector area of 1.13 million $\mathrm{m}^{2}$ [2].

In industries, heat energy is consumed mainly for three purposes: process/space heating, generation of steam/hot water, and product manufacture. Some common industrial applications include heating/cooling, dyeing, drying, cooking, and currying [3,4]. According to the U.S. Energy Information Administration (EIA), a leading agency located 
in Washington D.C., about $54 \%$ of the total delivered energy in the world is captured by the industrial zone [5]. Around $66.66 \%$ of the entire industrial energy requirement is for heat energy, and about $75 \%$ of the required heat energy is for industrial processes with temperatures below $400{ }^{\circ} \mathrm{C}$. As stated by IRENA, about $60 \%$ of the heating demands required for industrial purposes are below $250{ }^{\circ} \mathrm{C}$, which can easily be met by solar thermal energy [6].

Depending on the geographical and economic circumstances of a country, solar thermal energy can be supplied in the form of hot water, hot air, or steam up to $400{ }^{\circ} \mathrm{C}$ for a wide range of industries. For example, conventional flat plate or evacuated tube collectors (FPC, ETC) can easily provide temperatures below $100{ }^{\circ} \mathrm{C}$, whereas modified FPC/ETC with super high vacuum and concentrators can provide temperatures around $200{ }^{\circ} \mathrm{C}$ [6]. The types of processes also play a significant role in selecting solar collectors and the integration of solar systems into the conventional systems. The pivotal prospect of implementing solarassisted technologies in the global industrial sectors is the higher consumption of thermal energy than electrical energy. The limited resources of fossil fuels that are presumed to last until 2060, and the increasing GHG emissions are topical issues continuously prioritizing the replacement of fossil fuels with renewable energy sources [7]. Economically developed and industrialized domains in Europe, Australia, Asia, and North America are already practicing solar-based technologies in various industries. The developing countries are also exploring policies towards zero carbon emission industrial processes [8,9]. Major common obstacles in achieving solar-assisted process heating systems in industries are the low price of fossil fuels, the high installation cost of the solar equipment, and the lack of adequate study and research required for the integration of solar technologies into existing industries to exploit the offerings of unbounded solar energy [6,10-12].

So far, several research papers, including reviews and case studies regarding solar industrial process heating systems, have been published. Most papers discussed the categorization of industries that follow solar technologies based on industrial processes and temperature range, as well as the selection and comparative performance analysis of solar thermal collectors. Therefore, a comprehensive analysis reviewing the integration details of solar thermal plants in existing industries is essential to sustain research flow.

This paper aims to investigate the design parameters and integration strategies of SHIP systems into globally installed industries based on several contemporary case studies, review papers, methodology studies, and monitoring results. The analysed topics include the location of the integration point, what methodology was followed to reach the integration point, type and gross area of solar collectors, temperature range, installed thermal power, and storage capacity.

Finally, SHIP projects with supply level, process-level, and other integration points are identified and compared to access the rate of a particular integration location for a particular process. The investigated industrial sectors are Food, Agriculture and Beverages, Horticulture, Mining Textile, Leather Chemical, Pharmaceutical, Transport, Paper, Wood and Rubber, Metal Processing, and Manufacturing of Electrical Equipment and Machinery. An extensive literature study was conducted to comprehend the design parameters, barriers, and final outcomes of several running and demonstration projects. Since most of the previous literature has covered the categorization of industries suitable for solar process heat integration, this discussion is not included in this analysis.

It was found that solar heat integration at the supply level is higher for almost all of the cases compared to process-level integration. Although supply and process-level integration have their own advantage and disadvantages, the high effort required for the process-level integration is more likely to make the solar heat integration less interesting. Therefore, it is necessary to access the rate of integration at different levels for certain industrial processes investigated in this paper. Several SHIP components and integration concepts based on heat transfer medium (air/water) from the literature and attended projects are also briefly discussed. 
As the lack of proper and adequate study of solar installations hinders the expansion of SHIP plant growth, it is hoped this paper will be helpful for researchers and industry officials regarding a successful and more customized integration of solar process heat in industrial processes.

\section{Recent Studies on Solar Industrial Process Heat}

The integration of solar heat into industrial processes has proven to reduce fossil fuel consumption and to initiate a carbon-free environment, and there is an ongoing tendency towards implementing SHIP projects in a wide variety of industries. However, the research in this sector is quite minimal. Recent studies show very few papers that have taken into account the development of solar integration methodologies in industries along with a broad investigation of analytical approaches to finding out the most suitable integration layout, as discussed below.

Kalogirou et al., wrote an excellent review paper on the potential of solar heat for industrial processes. They compared five different types of solar thermal collectors under using the simulation software TRNSYS for the weather condition of Cyprus. Flat paper solar collectors provided satisfactory performance for lower temperature operations, whereas concentrating solar collectors were more suitable for high-temperature operations. However, it was concluded that, due to cheap fuel prices compared to the installation costs of the solar system, fuel-based systems are still more profitable than solar-based systems [13]. Frein et al., analyzed the integration of a solar thermal plant into the dyeing process at a textile industry in Tunisia, Italy. A suitable integration solution was found after analyzing three integration concepts based on heat recovery options and certain limitations in temperatures for different stages of the process [14]. Strum et al., studied solar system integration in a soy sauce production plant in Beijing. The authors investigate the cut in energy demand in the factory through both retrofitting for waste heat recapture and introducing solar energy. Two processes were analyzed: water preheating and steam generation. For the first process, flat plate solar collectors were the most suitable, whereas a cascade system comprising photovoltaic and flat plate collectors was the most effective for generating steam [15]. In another study, Eiholzer et al., [16] investigated solar thermal plant integration in a brewery located in Scotland. A time average model and time slice model were used to estimate heat recovery potentials to apply pinch analysis. Kumar et al., fabricated and experimented with a solar-based system for process heating purposes, comprising of a flat plate collector and a photovoltaic thermal collector connected in series. The authors mentioned stated the designed system was highly effective in reducing industrial fuel demand [17]. Moreover, Kumar et al., wrote a thorough review paper covering the worldwide developments of solar thermal technologies. The paper included a broad discussion on solar thermal collectors, including comparisons, and briefly studied other solar thermal technologies. The authors categorized solar thermal collectors according to the type of industrial operation performed, temperature range, and application of solar systems [9]. Sharma et al., reviewed solar heating for industrial processes, including a clear illustration of several integration concepts of solar thermal heating systems in industries [3]. Wüest et al., presented an effective way to increase solar gain by applying a controlled absorbing storage system while investigating a novel non-storage façade element. Such findings are very effective in optimizing consumed power by HVAC systems [18]. Znaczko et al., investigated malfunctions in heat pipe-based solar collectors and discovered the dependency of proper functioning of the heat pipe on geometrical fabrication and the amount of working fluid [19]. In a similar study, Kuczynski et al., investigated the connection between the geometrical aspects and efficiency of flat plate collectors and found that numerical models are very effective in building such correlations [20]. Ding et al., created a mathematical model to improve thermal conductivity and found a very positive impact of increasing transmittance of the transparent cover on the collector efficiency [21]. Farjana et al., analyzed the prospects of solar heating for industrial processes in the context of existing industries globally that have employed solar technologies in processing and manufacturing objects [8]. In another 
study, Farjana et al., investigated the potential of solar process heat integration in Austrian industries by comparing it with other countries enriched in SHIP implementation [22]. Farjana et al., analyzed the integration of solar heat in mining sectors in terms of environmental impact using Life Cycle Assessment methodology and later explored the prospects of solar heat integration in two different lead mining sites in Australia. It was found that evacuated tube solar collectors are more promising and ecological than flat plate collectors [23,24].

The subject of solar process heat integration is still at its early stage and requires further investigation. Significant gaps in research include the following,

- Most of the analyses were about the categorization of suitable industries for solar heat integration based on process type and related temperature range.

- The previous research primarily focused on the selection, comparative performance analysis, and development of solar collectors.

- Investigation of the development and modification of solar process heat integration was rarely found.

In this paper, the authors attempt to review and summarize globally installed SHIP plants, keeping the main focus on integration particulars. The general approach to organizing the findings is given below.

1. Industries with solar process heat integration were identified and grouped by various sectors in the global context.

2. The existing SHIP plants were analyzed based on the point of solar integration.

3. The rate of supply-level integration against process-level integration was identified and compared for various industrial sectors for particular processes.

4. Significant design factors were identified and listed for running and demonstration of SHIP plants by analyzing substantial literature. Notable design factors include process type (batch, continuous or other), methods to determine suitable integration points, integration point location, details of the installed solar collector, storage tank volume, temperature range, and simulation tools. Difficulties that were faced during the project implementation and project findings were added.

\section{Basic Components of SHIP Systems}

The integration of solar technologies into an industrial process system requires the amalgamation of several elements, such as solar energy harnessing machinery which could be solar thermal (ST), solar photovoltaics, hybrid collectors, thermal storage systems, heat exchangers, piping, and valves for the interconnection of all these components.

\subsection{Solar Collectors}

In a solar-based system, a solar collector plays the lead role in capturing solar irradiation and converting it to a useful form of energy such as heat or electricity, or both in a hybrid system. A solar collector acts as a heat exchanger by transferring the heat energy from falling solar radiation to the sensible heat of a working fluid. Owing to the broad range of working temperatures, nearly every type of solar thermal collector can be used in industrial process heating systems [25-28].

\subsubsection{Types of Solar Collectors in SHIP Systems}

Generally, three types of solar thermal collectors are recognized for industrial process use: (a) flat plate; (b) evacuated tube, and (c) concentrating collectors $[3,9,28]$.

(a) Flat plate solar collectors (FPCs) are the simplest form of solar thermal collectors. The main parts of a flat plate collector are the absorber plate and aluminum/copper tubes containing a working fluid. The absorber plate can be metallic (copper, aluminum, etc.) or plastic. The heat transfer fluid can be both air and water. The tubes are either welded or build-into part of the plate. For this reason, proper welding technology is required to secure the satisfactory performance of the solar collector. In a wide range of industries such as food, dairy, paper, chemical, textile, beverages, and plastics, 
several processes require temperatures below $100{ }^{\circ} \mathrm{C}$. For such kinds of industrial applications, flat plate solar collectors are the best pick. The main advantages of a flat plate collector are simple structure, long-lasting properties, easy maintenance, and low price. The disadvantages are that they lack a sun-tracking system and, for operating temperature more than $70^{\circ} \mathrm{C}$, the collector efficiency decreases due to convective heat loss $[8,13,25-27,29,30]$.

(b) Evacuated tube solar collectors (ETCs) consist of several concentric glass tubes with evacuation between the two layers. The outer surface of the inner tube contains the selective coating in a vacuum. All the glass tubes are connected to the main header pipe. Due to the presence of the vacuum, there is less convective heat loss and the coating lasts a long time. Like flat plate collectors, evacuated tube collectors can collect both direct and diffuse solar radiation. However, because of vacuum insulation and high-quality surface coating, the efficiency of ETC is higher than FPC. Another advantage of ETCs is that they perform very satisfactorily even in cloudy/cold weather conditions. The operating temperature range for evacuated tube solar collectors varies from $50{ }^{\circ} \mathrm{C}$ to $200{ }^{\circ} \mathrm{C}$.

(c) As the name indicates, concentrating collectors are solar technologies that concentrate solar radiation. Concentrating solar collectors mainly comprise a concentrator and a receiver. The function of the receiver is to transform the incident solar beam into heat energy while the concentrator points the solar beam towards the receiver. Such collectors usually require a solar tracking system. Depending on whether the image of the sun is formed on the receiver or not, concentrating collectors are classified as imaging and non-imaging concentrating collectors, respectively. The achievable temperature range of concentrating collector is from $150{ }^{\circ} \mathrm{C}$ to $400{ }^{\circ} \mathrm{C}$. Types of concentrating collectors (imaging and non-imaging) are as follows:

(I) Compound parabolic collector (imaging)

The followings fall in the non-imaging category:

(II) Parabolic Trough Solar Collector (PTSC)

(III) Linear Fresnel Reflector (LFR)

(IV) Parabolic dish reflector (PDR)

(V) Central receiver/Heliostat field reflector

Despite having total utilization capacity for industrial process heating systems, concentrating solar collectors are not applied to a satisfactory level in this sector, except for power plants [31].

\subsubsection{Selection Criterion for Solar Collectors}

To obtain the most appropriate result from the integration of a solar thermal system to an industrial operation, it is necessary to consider some factors. Such design aspects are included in the standard design handbook by the solar energy research institute (SERI), presently known as the National Renewable Energy Laboratory (NREL) funded by the U.S. Department of Energy, and also in the report of The International Renewable Energy Agency (IRENA), as well as in a few research papers. Factors to be taken into account for the selection of a suitable solar collector for use in some industrial process are given below $[3,6,26,32]$.

Primary selection criterion:

(a) Average operating temperature of the solar collector

(b) Optical efficiency and overall heat transfer coefficient of the collector

(c) Overall solar irradiance on the factory site

(d) Cost

(e) Availability of space and the possibility of roof integration

In the design report of SERI, the selection of solar thermal collectors is a two-step process: the primary selection and the final pick up of a suitable band [26]. There is a comprehensive analysis and a step-by-step illustration about selecting the most suitable 
solar collector technology for the SHIP system. Based on the data presented in the report, an algorithm was built, as presented in Figure 1.

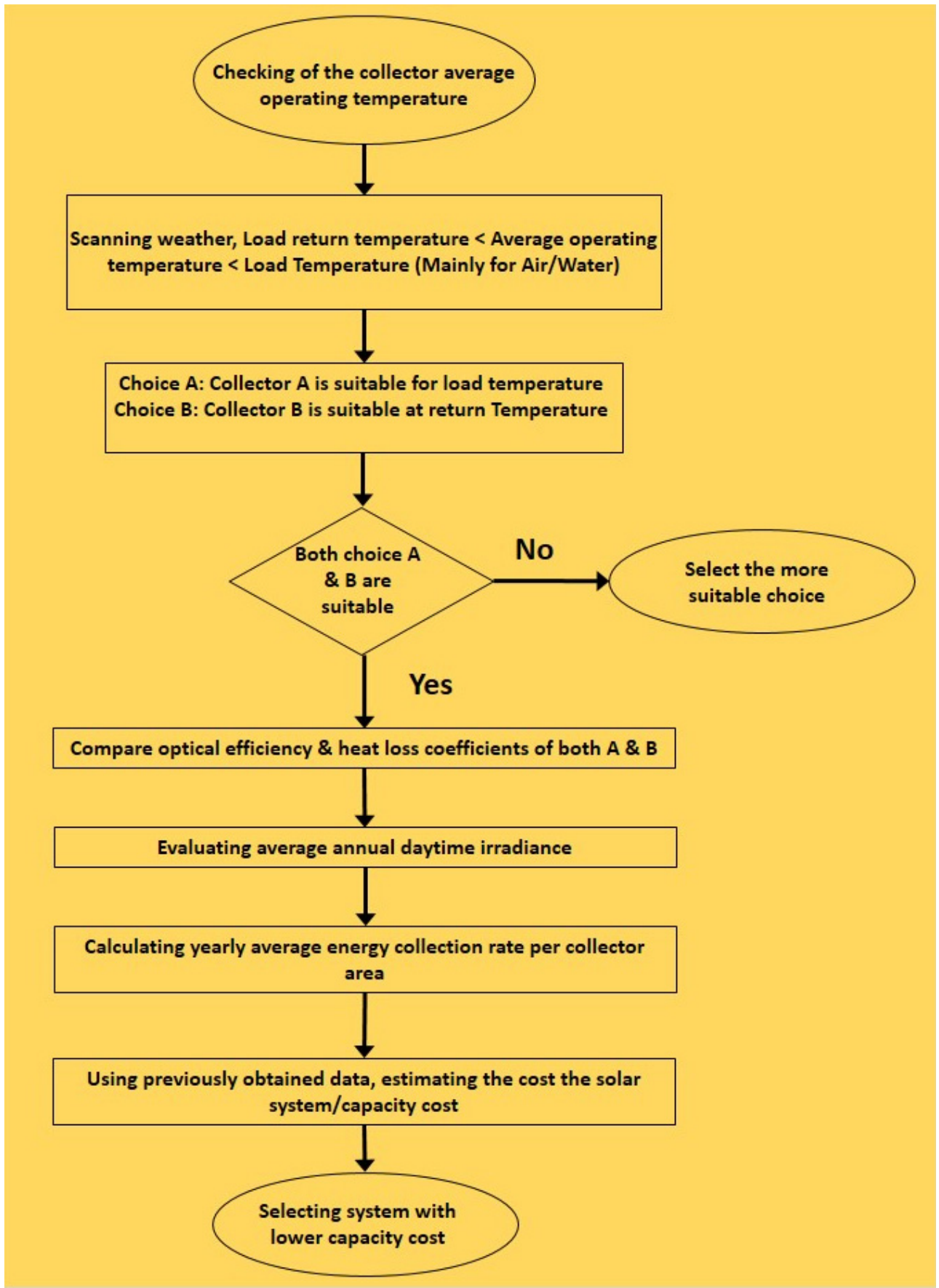

Figure 1. Steps to select a preferable solar collector for a SHIP system, modified from TR-253-1356 by SERI [26].

\subsubsection{Heat Exchangers}

Heat exchangers are mechanical systems that transfer heat energy between two or more fluids and are crucial elements for various industrial processes. Heat exchangers can be classified according to the heat transfer method, whether the two fluids are in direct contact or not, the number of participating fluids, compactness of the surface, design aspects, fluid flow arrangements, and the mode of heat transfer. Some of the important types of heat exchangers for industrial process heating purposes are shell and tube heat exchangers, plate- 
type heat exchangers, spiral plate heat exchangers, lamella heat exchangers, and extended surface heat exchangers. Shell and tube heat exchangers are tubular heat exchangers and are extensively used in chemical industries and power plants for space heating and cooling purposes. Plate-type heat exchangers are best suited for food, beverage, dairy, juice, alcohol, and pharmaceutical industries. Of the other types, lamella heat exchangers are widely used in chemical, paper and pulp, and general industrial processes, whereas spiral plate heat exchangers are used in cellulose factories as kettle reboilers [33].

\subsubsection{Piping Systems}

Piping systems for industrial plants are of two categories: process piping systems and utility piping systems. Process piping systems are of two types, primary systems and secondary systems. Primary piping systems are directly involved in the treatment of material, secondary piping systems are related to the further refining of the material, and utility piping systems are for maintaining and aiding the primary piping systems [34].

According to the design directories of SERI, presently known as NERL, pipings have a significant impact on the SHIP system cost and performance. Three configurations are fundamental for solar process heating systems in industries: direct return, reverse return, and central feed, as shown in Figure 2 [35]. The reverse return system faces less pressure drop than the direct return, although both of the systems require balance valves. With the central feed layout, the system can reduce the number of necessary pipes.

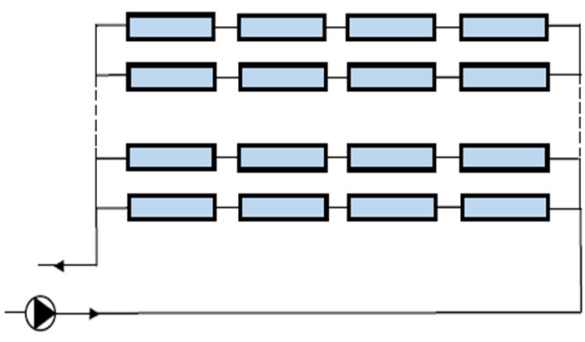

(a)

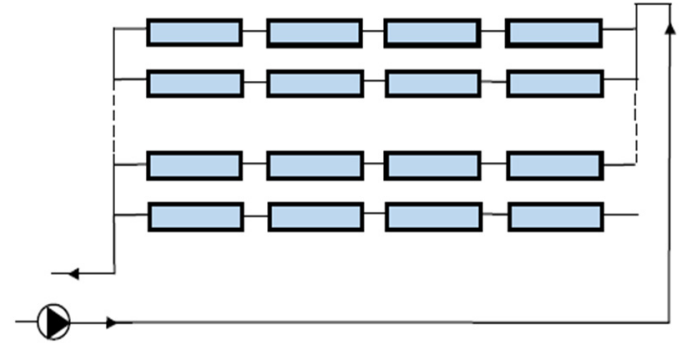

(b)

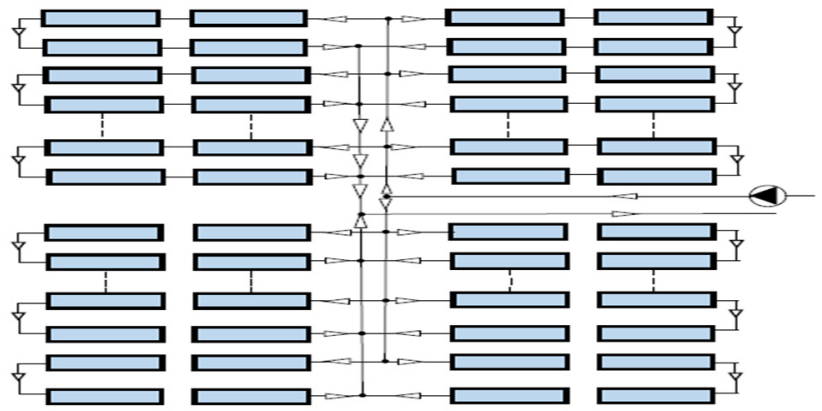

(c)

Figure 2. Piping layouts in industrial processes: (a) Direct Return, (b) Reverse Return and (c) Central Feed. Adapted from Ref. [35]. Copyright (2012), with permission from Elsevier.

\subsubsection{Storage Systems}

A consistent problem in solar industrial process heating systems is the inconsistency between the demand and the supply of solar power due to unpredictable weather conditions. Hence, an energy storage system has the potential to enhance the thermal performance and effective regulation of SHIP systems. Energy can be in several forms, such as chemical, electrical, or thermal, and it is possible to store every form of energy using a special kind of device called an energy storage/accumulator. However, the thermal energy storage 
system (TES) is the best-suited technology for solar process heat in industries and power plants. Based on storage media, TES is classified into three types: (1) sensible heat storage; (2) latent heat storage, and (3) chemical heat storage [36-38].

1. Sensible heat storage (SHS)

A sensible heat storage system is based on the sensible heat of the storage material that is usually held in a container connected to an inlet/outlet pipe. The storage materials can be solid or liquid. Examples of solid materials for sensible heat storage include concrete, sand rock minerals, ferroalloy metals, and fire bricks. Liquid storage materials involve water, minerals, synthetic oils, and molten salt, among others. Nevertheless, water is the most favored storage medium, being the cheapest, and is extensively used for industrial and domestic purposes.

\section{Latent heat storage (LHS)}

Several materials can store/release a large amount of heat energy during a phase change (for example, from solid to liquid) and are called phase change materials (PCMs), such as paraffin compounds. In a latent heat storage system, PCMs are used as heat sources. There are principally three types of PCMs for thermal applications: organic, inorganic, and eutectic. The main advantage of latent heat storage is that it requires a smaller space compared to sensible heat storage.

\subsubsection{Heat Pumps}

Industrial heat pumps are also referred to as active heat recovery apparatus since they are used to elevate the temperature of a waste heat stream to make it more applicable. The application of heat pumps is quite advantageous for industrial purposes because they utilize waste heat that saves fuel; hence, a cost-saving takes place. Various types of heat pumps are used in industries. Examples of some frequently used heat pumps include Closed-Cycle Mechanical Heat Pumps, Open-Cycle Mechanical Vapor Compression (MVC) Heat Pumps, Open-Cycle Thermo compression Heat Pumps, and Closed-Cycle Absorption Heat Pumps. Suitable industrial sectors for the application of heat pumps include wood, chemical, pharmaceuticals, petroleum refining, food, and beverages, among others $[39,40]$.

\section{Basic Integration Layouts of SHIP Systems}

For the successful implementation of solar technology in industrial process heating, one of the most crucial aspects is the integration concept/system design of solar heating systems. Until now, there have been no strict rules for integrating solar heating systems into an industrial process. However, several research projects have led to basic design concepts of SHIP systems based on factors such as operations performed, including preheating of boiler feed water and heating of fluid stream. Back in 1978, based on several SHIP projects undertaken by the U.S. Department of Energy's laboratory SERI, some basic integration concepts were illustrated in their design handbooks [26]. Sharma et al., mentioned and briefly described several design approaches, as well as methods analyzed or evolved by several researchers under SERI projects [3]. Some of the viable design concepts from the SHIP project reports by SERI are summarized below.

\subsection{Solar Hot Air Systems}

Hot air systems are very capable of meeting industrial process heating requirements. Examples include drying of food products, preventing deterioration of food products, maintaining and upgrading product quality, and easing the transportation of food products. [6]. Hot air systems can be direct or indirect. A direct hot air system has a very simple layout with a solar collector to heat the air and a pump to deliver the heated air to the process. An auxiliary heater can be used if the temperature of the heated air fails to meet the process requirement. In an indirect solar hot air system, the heat energy is provided to the air via a heat exchanger. The schematics of both systems are illustrated in Figure 3. 


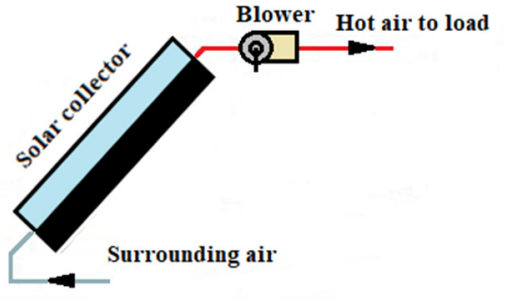

(a)

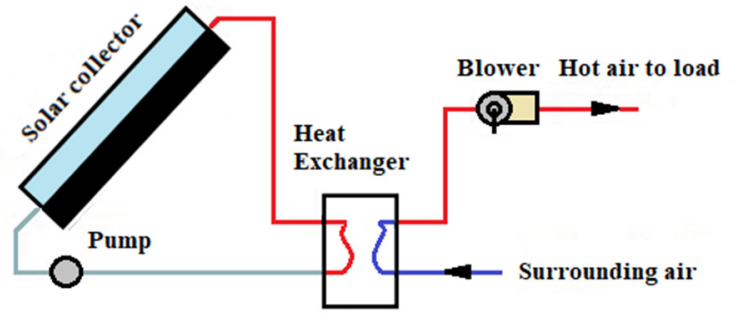

(b)

Figure 3. Solar hot air system: (a) Direct air system, (b) Indirect air system. Adapted and modified from Ref. [41], Copyright (2012), with permission from Elsevier.

\subsection{Solar Hot Water Systems}

A solar hot water system can be of the direct type or indirect type.

\subsubsection{Direct Solar Hot Water Production System}

A direct solar hot water system is like a direct solar hot air system with the process water being the working fluid that passes through the solar collector. A direct solar hot water system can be with or without storage. Based on the piping layout, a direct solar hot water system with storage for a non-freezing working fluid can have four classifications: Four-Pipe Storage, Two-Pipe Storage, Multiple Tank Storage, and Variable-Volume Storage Configuration, all presented in Figure 4.

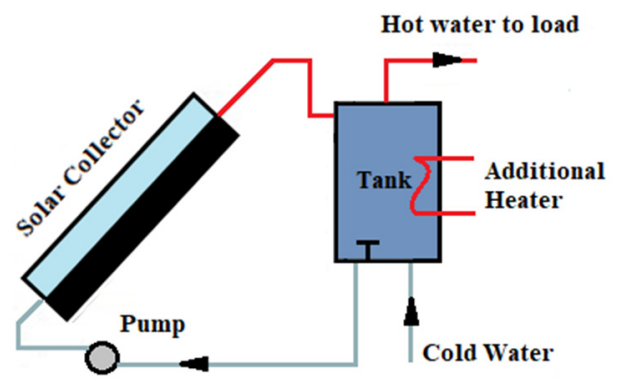

(a)

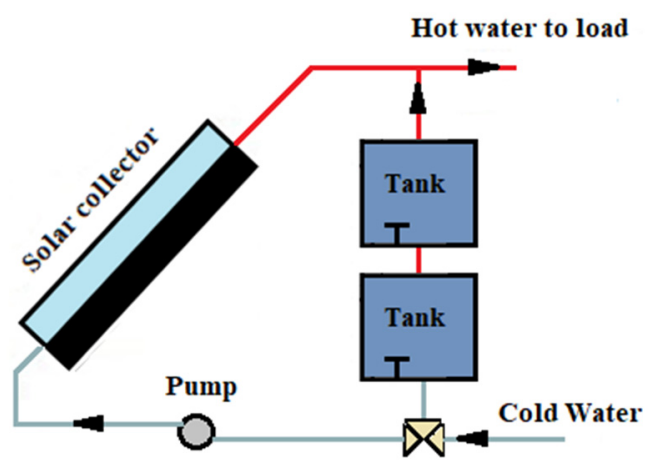

(c)

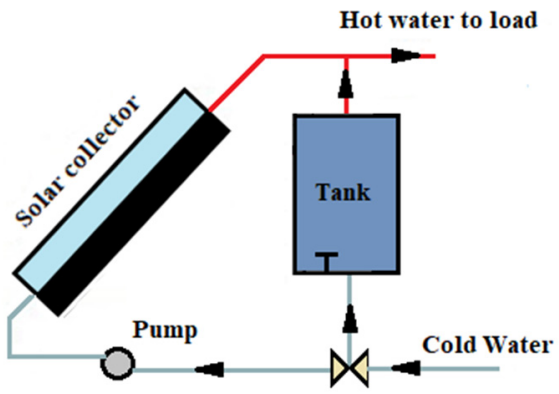

(b)

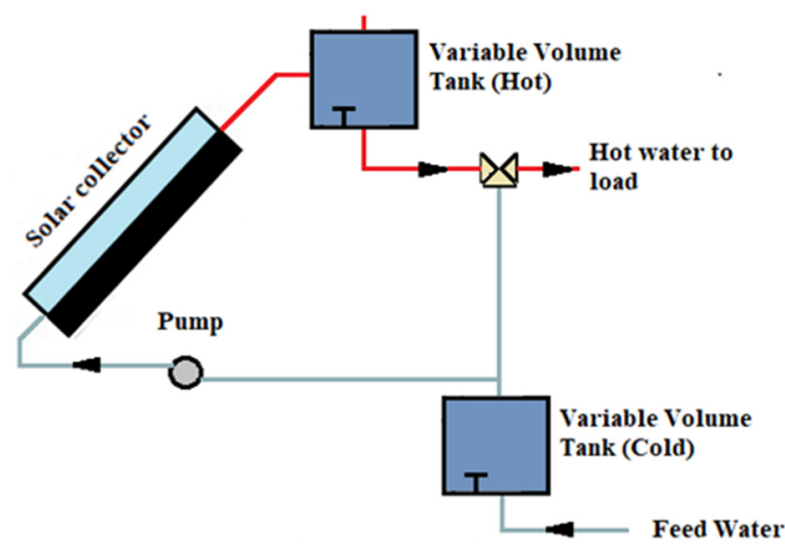

(d)

Figure 4. Four configurations of direct solar hot water systems: (a) Four-pipe arrangements, (b) Twopipe arrangements, (c) Multiple tank storage, (d) Variable-Volume storage. Adapted and modified from Ref. [42], Copyright (2018), with permission from Elsevier. 
The Four-Pipe Storage Configuration is suitable for space heating and residential applications. One disadvantage is that the collector inlet temperature might exceed its limit as the collector is fed from the mixed tank at a temperature nearly that of the load supply. However, controlling this system is very convenient irrespective of the application area.

A two-pipe storage layout is a modification of the four-pipe arrangement with both the inlet and outlet pipes amalgamated to pass through a single storage tank. Such systems provide better performance than the four-pipe storage configuration by solving the problem of an excessively heated collector inlet. Nevertheless, one big disadvantage is that the solar collector and the storage cannot supply heat energy at the same time unless the load flow rate is higher than the collector flow rate.

A multiple tank storage arrangement provides better performance than a two-pipe storage configuration by keeping the collector inlet temperature under the load supply temperature when there is no load. Such aspects allow this system to have a better thermocline state. Nevertheless, such systems are quite expensive and involve heat loss.

A variable volume storage system delivers better performance than the other three configurations. Such systems consist of two variable storage tanks, one for hot fluid and the other for cold fluid. In no-load conditions during the daytime, cold water passes through the solar collector and is stored in the hot tank. In the off-period, hot water can be taken out of the hot tank for use. However, a variable storage system does not provide good performance in cloudy weather.

\subsubsection{Indirect Solar Hot Water Production System}

An indirect solar hot water system has quite a simple layout with a solar collector, two fluid loops, and a heat exchanger. In an indirect solar water system, antifreeze protection usually involves the application of an antifreeze solution/heat oil in the solar collector loop.

\subsection{Steam Generation Systems}

In industrial process heating, steam is used as a highly preferred heat transfer medium due to its low cost and relatively low toxic nature compared to other types of fuels. Usually, steam-based systems are preferred in direct/indirect industrial processes with temperature requirements within about $200{ }^{\circ} \mathrm{C}[22,43]$.

\subsubsection{Indirect Steam Generation System}

An indirect steam generation system usually consists of a collector loop with a heat transfer fluid to produce heat energy to be transferred via a heat exchanger to another fluid (normally water or air) to produce steam/hot air/hot water under pressure as per industrial process requirement. An indirect solar steam generation system can be achieved by five configurations, as described below.

\section{- Unfired Boiler Steam Generation System without Backup}

An unfired boiler system generally employs concentrating solar collectors and a low vapor pressure antifreezing working fluid, such as hydrocarbons, thermal oil, or glycol in the collector loop. The heat transfer fluid circulates in the collector loop and provides heat energy to the feed water in the boiler to produce steam. A schematic of an unfired boiler steam generation system is shown in Figure 5. 


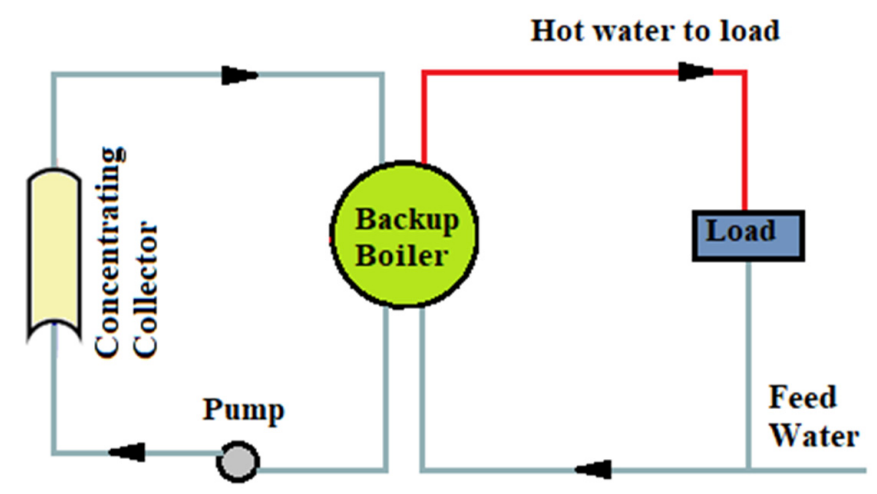

Figure 5. Indirect steam generation system with unfired boiler without backup. Adapted from Ref. [3], Copyright (2017), with permission from Elsevier.

- Unfired Boiler Steam Generation System with Backup in Parallel Connection

Indirect steam generation with an unfired boiler can also be configured with a boiler back up connected in parallel to assist the system during operating hours lacking sunshine, as presented in Figure 6.

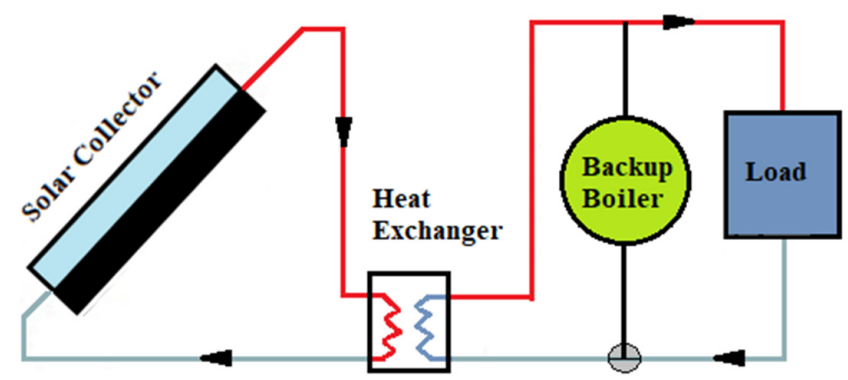

Figure 6. Indirect steam generation system with unfired boiler containing the backup. Adapted from Ref. [44], Copyright (1985), with permission from Elsevier.

- $\quad$ Flash Boiler Solar System for steam Generation without Backup

A flash boiler steam generation system incorporates concentrating solar collectors along with a throttling valve called a flash valve and a flash tank. In such systems, pressurized water circulates through the concentrating solar field, and then the pressurized hot water passes through a flash valve where the pressure drop takes place and the water flashes to steam in the flash tank, which also acts as a separator that contains both the steam and the liquid water. From the separator, the steam is supplied to the process and the liquid water returns to the collectors. Figure 7 illustrates a flash boiler steam generation system without backup.

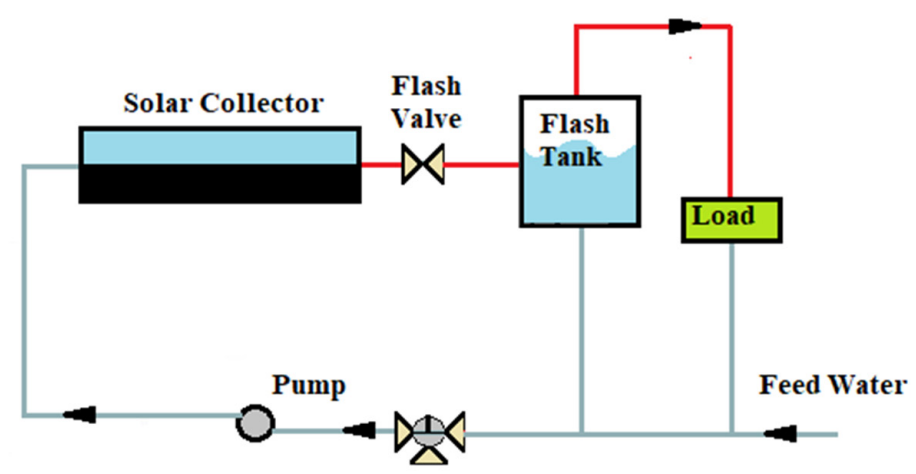

Figure 7. Indirect steam generation system with flash boiler without backup. Adapted from Ref. [44], Copyright (1985), with permission from Elsevier. 
- $\quad$ Flash Boiler Solar System for steam Generation with Backup in Parallel

A flash boiler steam generation system can also be fabricated with an auxiliary boiler backup connected in parallel for dull weather with adverse solar intensity. Figure 8 presents a flash boiler steam generating system with boiler backup.

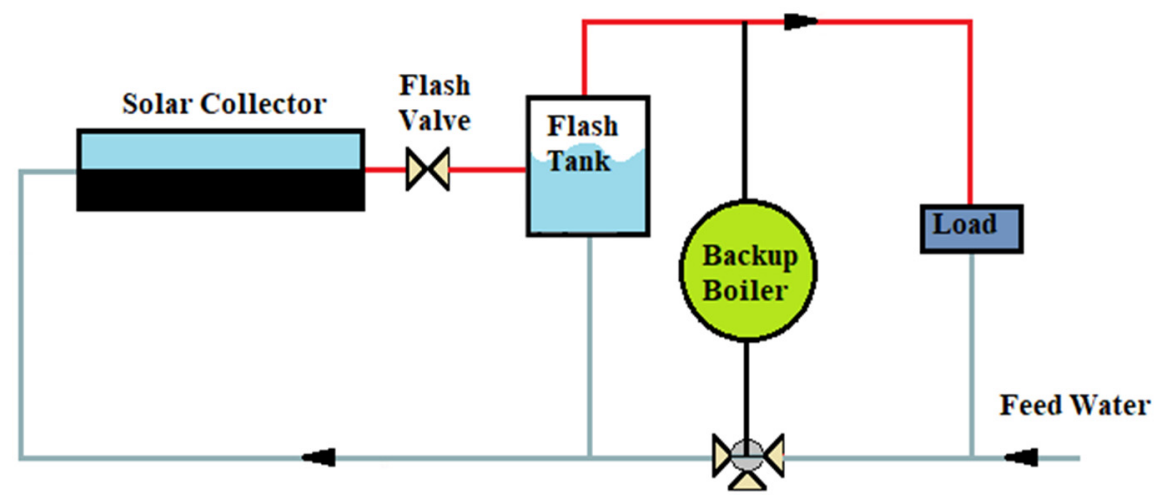

Figure 8. Indirect steam generation system with flash boiler with backup. Adapted from Ref. [44], Copyright (1985), with permission from Elsevier.

- Heat Exchanger based Steam Production with Backup in Series Connection

In an indirect solar steam generating system applying heat exchangers, boiler backup can also be arranged in a series connection with the solar collectors, as presented in Figure 9.

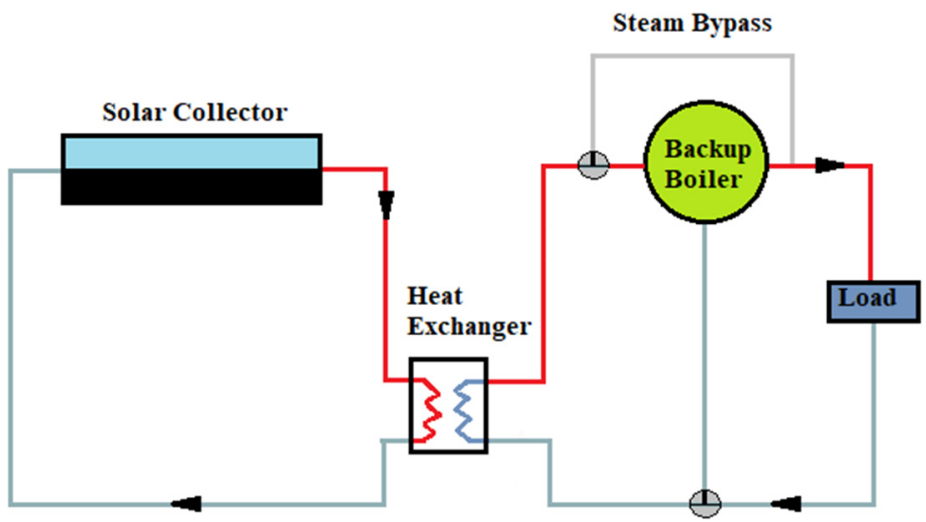

Figure 9. Heat exchanger-based steam generation system with backup in series connection. Adapted from Ref. [44], Copyright (1985), with permission from Elsevier.

\subsubsection{Direct Steam Generation Systems}

A direct steam generating system excludes the use of a heat exchanger and can contain the backup boiler both with series or parallel connection, as illustrated below.

- Direct Steam Producing System with Backup in Parallel Connection

A direct steam generating system is shown in Figure 10 where the backup boiler is connected in parallel with the solar collectors. Water flows through the solar collectors and is fed directly to the process. 


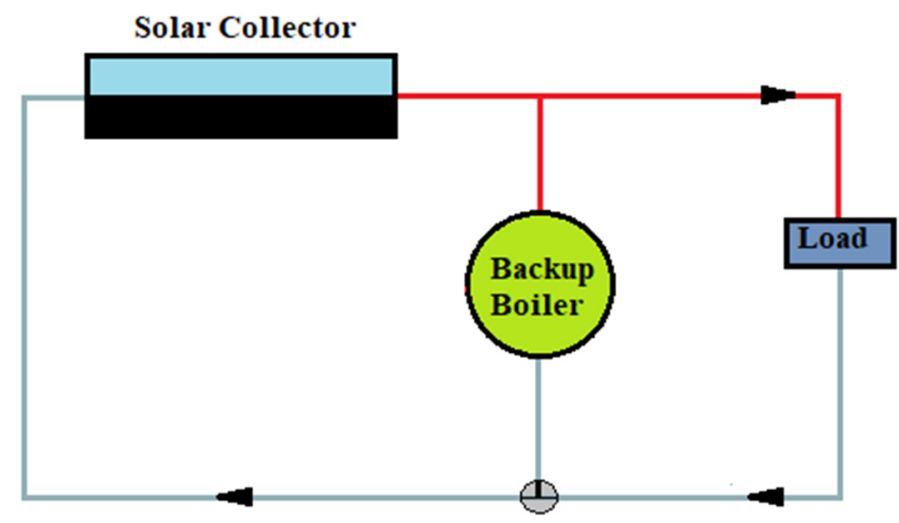

Figure 10. A direct steam generating system with a backup boiler in a parallel connection. Adapted from Ref. [44], Copyright (1985), with permission from Elsevier.

- Direct Steam Producing System with Backup in Series Connection

In a direct steam production system, the backup boiler can also be connected in series with the solar collectors as depicted in Figure 11.

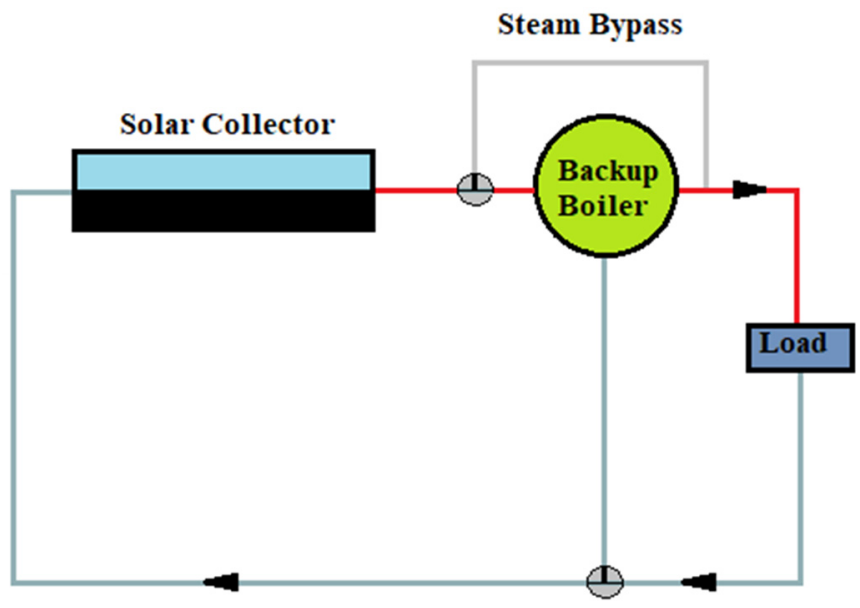

Figure 11. A direct steam generating system with a backup boiler in series connection. Adapted from Ref. [44], Copyright (1985), with permission from Elsevier.

\section{Approaches towards Solar Industrial Process Heat Integration}

\subsection{Solar Heat Integration Methodologies from Literature}

Suitable design propositions and appropriate integration layouts have always been a core subject of investigation for researchers to obtain better performance from SHIP integration. Several approaches are available from the literature for the development and evaluation of suitable solar heat integration methodologies, such as time-slice model (TSM), time average model (TAM), total site analysis (TSA), and pinch analysis.

Industrial processes can be both continuous and batch processes. In batch processes, the heat exchange between the hot and cold utilities is limited [45]. Depending on the mode of operations, not all the integration approaches can provide the same solution.

Pinch technology is a popular and widely used methodology for the perusal of industrial processes, more particularly to locate the least permissible temperature difference between the hot and cold utility. The term pinch analysis derives from the term pinch technology, and also refers to the use of mechanisms, Socratic methods, and algorithms to reach the pinch point and thus find the most suitable integration concept for financial savings. Linhoff and Flower, and Umeda et al., first introduced pinch analysis as two individual research groups [45,46]. 
For batch processes, two commonly used approaches are the Time Average Model (TAM) and Time Slice Model (TSM), both developed by Kemp and Macdonald [47-49]. Both TAM and TSM methodologies were originated from pinch technology; however, the main distinction between them is the consideration of time factors such as process scheduling or time availability. In TAM, the operations of a batch process occur ignoring the sequence, and at any time. In TSM, the beginning and the finishing time of the involved operations can be integrated, and, within these slices, heat integration can be performed as a continuous process $[45,50]$.

Another design approach is Total Site Analysis (TSA), which involves thermal profiles of the source and sinks site i.e., the total site, as developed by Dhole and Linnhoff in 1993. In the TSA method, grand composite curves (GCCs) of the associated processes of a central system are used to build the site source-site sink profiles (SSSP) which help to reach the optimal design considerations. Perry, Varbanov, Chew et al., and Matsuda [51-55] further evolved the TSA method. In 2019, Abdelouadoud et al., presented a further modification of the Time Average Model (TAM) in which the impediments and the degree of freedom of Indirect Sources Sinks Profiles (ISSPs) were graphically identified to fabricate the heat exchanger storage network for targeted heat recovery [56].

Nemet et al., modeled two curves, namely, the Captured Solar Energy Curve and the Minimal Capture Temperature Curve, to reach the optimal solar integration outcomes via graphical evaluation [57]. In another study, Nemet et al., investigated a solar thermal integration strategy for batch processes based on the Time Slice Model (TSM) to address the varying availability of solar radiation [50].

Baniassadi et al., developed a procedure to deduce the solar fraction targets for a definite solar collector area. In their later work, Baniassadi et al., introduced an analytical concept to obtain better solar integrated systems with heat storage based on an ideal division of obtainable solar energy among the available direct heat exchangers and storages [58,59]. Abdelhady et al., presented a design strategy based on a hierarchical and a common algorithmic approach for the integration of solar heat in cogeneration systems [60]. Rashid et al., investigated the process intensification of a hybrid power plant run on both solar energy and natural gas. They proposed a theory of Flexible Heat Integration (FHI) to apply to the hybrid power plant. The main theme of the FHI concept is to allocate solar heat to different processes based on the associated temperatures of the processes. For example, with high solar irradiation, the solar collectors provide heat to processes that require high temperature, keeping the additional heating source off. For average solar irradiation, the solar collector serves the medium temperature processes leaving the higher temperature processes for supplemental heating sources. As mentioned by the authors, the radiative heat transfer can be lowered under FHI methodology, and also a real-time optimization strategy can be used to assist the system in selecting the temperature of heat accumulation as well as the point of heat distribution [61].

\subsection{Steps to Identify the Optimal Integration Points}

Although various industrial sectors are becoming interested in implementing SHIP projects, most of the solar heat integrations have been made by paying more attention to developing the collector's design, categorizing industries by similar unit operations, conceptual assumptions regarding the overall heat demand, the temperature level of the processes, the production rate of the factories on a monthly/yearly basis and the statistics from single demonstration plants. Specific instructions for the integration of solar thermal process heating systems in existing industrial plants are not firm yet. However, some general guidelines have been constructed, as published by the International Energy Agency under task 49 of The Solar Heating and Cooling Programme (IEA SHC Task 49), based on the Ph.D. thesis of Bastian Schmitt [62]. Some major steps were established along with some leading factors as presented in Figure 12. For the overall grouping of SHIP integrating systems, three leading parameters were identified, such as the assessment of the existing integration strategies, heat transfer medium, and the difference in the heat integration 
between the supply level and process-level. Besides, clear distinctions between supply level and process-level were found to be necessary for identifying the specific boundary conditions of suitable solar process heat integration in industries $[62,63]$.

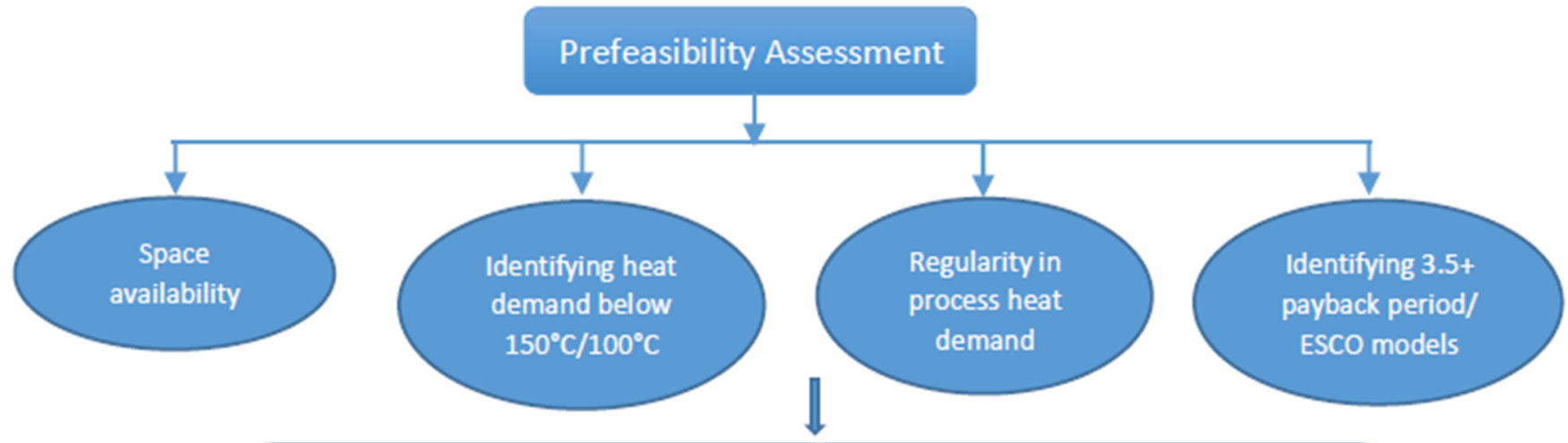

Company assessment:

- Visiting the production site to assess heat supply system/ existing load profiles

- Gathering, outlining and analyzing diagrams with the company staffs

- Preparing energy balance and process flow sheet

- Investigating heat consumption by each unit process

- Verification of the collected data by crosschecking with standard values

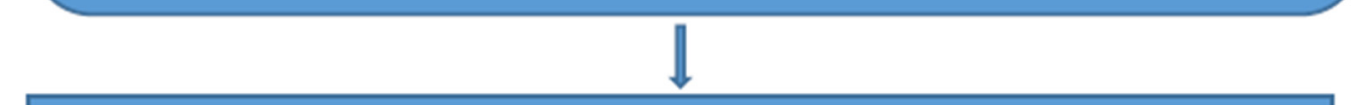

Identifying significant heat loads by analyzing load profile, process temperature, apparatus, working fluid temperature and heat recovery

Comparison among suitable integration points for final selection

Figure 12. Steps towards the selection and identification of suitable integration points of solar process heat integration in industries. Modified from [63,64].

One very easy distinction between the supply level and process-level concerns the destination of solar heat supply. If the solar heat is supplied to the boiler house to contribute to steam/hot water generation it is called supply level integration, whereas if the solar heat is supplied directly to a process it is called process-level integration. In the case of supply-level integration, generated heat from the boiler is provided to a central heat distribution system using heat exchangers. Based on the type of heat transfer fluid (liquid or steam) the selection of heat exchangers is made, which further leads to different integration concepts. In the case of process-level, the integration concepts are selected based on the category of heat consumers and the type of conventional heating apparatus. The type of heat consumers refers to how heat energy is being utilized, such as preheating of the product/process medium, heating or temperature maintenance of industrial baths, or thermal separation processes (drying, evaporation, distillation) [62-64].

Detailed distinctions between the supply side and process side are presented in Table 1 [62-64]. 
Table 1. Difference between heat integration at the supply level and the process-level.

\begin{tabular}{|c|c|}
\hline Supply Level & Process-Level \\
\hline $\begin{array}{l}\text { Integration at the supply level is mainly related to the } \\
\text { generation and/or distribution of heat from the boiler house }\end{array}$ & $\begin{array}{l}\text { Integration at the process-level is mainly associated with the } \\
\text { application of heat to the process either directly or using a } \\
\text { heat exchanger }\end{array}$ \\
\hline $\begin{array}{l}\text { The primary determiner of optimal integration point: } \\
\text { Associated heat transfer medium. } \\
\text { Ex: Steam, Liquid medium (water, air, thermo oils, etc.) }\end{array}$ & $\begin{array}{l}\text { The primary determiner of optimal integration point: Types of } \\
\text { heating applications / heat transfer technology. } \\
\text { (a) Preheating, (b) Heating and maintenance of temperature and } \\
\text { (c) Thermal separation process }\end{array}$ \\
\hline $\begin{array}{l}\text { Heat transfer medium and integration point can provide an } \\
\text { optimum integration concept of the total system }\end{array}$ & $\begin{array}{l}\text { Various integration concepts can lead to relevant } \\
\text { integration points }\end{array}$ \\
\hline Choice of heat exchanger depends on heat transfer media & $\begin{array}{c}\text { Choice of heat exchanger depends on heat consumer types and } \\
\text { vice versa }\end{array}$ \\
\hline
\end{tabular}

Integration concepts for steam as heat transfer medium:

(a) Direct/indirect generation of steam using solar energy by parallel integration

(b) Heating of boiler feed water by series integration

(c) Heating of make-up water by series integration

Integration concepts for liquid heat transfer medium:

(a) Parallel integration of solar heat into hot water circuits (Direct/Indirect)

(b) Preheating return flow by serial integration

(c) Heating of storage/cascades

The conventional way of heating is not taken into consideration

Three basic integration concepts are available:

(a) Integration of an additional external heat exchanger

(b) Integration of an additional internal heat exchanger

(c) Generation of steam using solar power at zero (vacuum) or low pressure

Considers conventional way of heating (heating by heat exchangers or direct steam injection)

\section{Status of Integration Parameters of Solar Process Heat in Existing Plants}

SHIP projects are being carried out worldwide in a wide range of industries and power plants. The most promising industrial sectors for solar process heat integration are food, textile, and mining. According to the ship plant database, a very useful online portal, developed by AEE-Institute for Sustainable Technologies (AEE INTEC), about 346 plants exist in 44 countries worldwide. In 2020, countries having the highest number of SHIP installations were China, Mexico, Germany, India, and Spain, with a total number of 30, 16, 10, 3, and 3 projects, respectively. Other important countries were Belgium, Austria, Cyprus, Italy, Malaysia, Morocco, the Netherlands, and Turkey $[2,65,66]$. In the following sections, the integration parameters for globally installed plants with solar process heat integration are discussed.

\subsection{Global Integration Scenario in the Food Industry}

The food industry is the most prominent industrial sector, including the food manufacturing, beverage, and agriculture sectors, for solar integration with low-temperature processes $\left(<150{ }^{\circ} \mathrm{C}\right)$. Together, food and beverages share $47 \%$ of the total globally installed projects [2]. In the agriculture sector, solar process heat is gaining the potential for greenhouse heating in horticulture and for preserving fruits and vegetables. The most common operations in the food industry include general process heating, pasteurization, cleaning, cooking, space heating, and drying [67-69]. Table 2 shows the global scenario of solar process heat integration for both supply-level and process-level integration with other significant parameters for the food manufacturing, beverage, and agriculture industries. Table 3 presents the integration scenario for the horticulture industry $[66,70,71]$. 
Table 2. Integration scenario in existing SHIP plants for Food Industry [70,71].

\begin{tabular}{|c|c|c|c|c|c|c|c|c|}
\hline $\begin{array}{c}\text { Installation } \\
\text { Site }\end{array}$ & Company Name & Supplier & Application & Integration Point & Collector Type & Gross Area $\left(\mathrm{m}^{2}\right)$ & $\begin{array}{c}\text { Installed Thermal } \\
\text { Power }\left(\mathrm{KW}_{\mathrm{th}}\right)\end{array}$ & $\begin{array}{c}\text { Temperature } \\
\text { Range }\end{array}$ \\
\hline $\begin{array}{l}\text { Issoudun, } \\
\text { France }\end{array}$ & $\begin{array}{l}\text { Brewery in } \\
\text { Issoudun }\end{array}$ & Savosolar & Drying malt & Process-level & Flat Plate & 14,252 & 9976.4 & $55 \sim 90$ \\
\hline Mexico & $\begin{array}{c}\text { Zacatecas } \\
\text { Termosolar Drying } \\
\text { Plant }\end{array}$ & Modulo Solar & Chile drying & Supply level & Flat Plate & 125 & 87 & $50 \sim 85$ \\
\hline $\begin{array}{c}\text { San } \\
\text { Lorenzo, } \\
\text { Honduras }\end{array}$ & Agrolibano & $\begin{array}{l}\text { Modulo } \\
\text { solar }\end{array}$ & $\begin{array}{l}\text { Water preheating } \\
\text { for sterilization }\end{array}$ & Supply level & Flat Plate & 44 & 30.8 & $60 \sim 70$ \\
\hline $\begin{array}{l}\text { Lhasa, Tibet, } \\
\text { China }\end{array}$ & & Vicot & $\begin{array}{l}\text { Preheat for } \\
\text { agricultural } \\
\text { drying }\end{array}$ & - & Parabolic Trough & 5000 & 3500 & - \\
\hline Romania & $\begin{array}{l}\text { Aroma Plant } \\
\text { Romania }\end{array}$ & $\begin{array}{c}\text { Grammer Solar } \\
\text { GmbH }\end{array}$ & $\begin{array}{l}\text { Medicinal plants } \\
\text { drying }\end{array}$ & Process-level & Air Collector & 80 & 56 & - \\
\hline $\begin{array}{l}\text { Limassol, } \\
\text { Cyprus }\end{array}$ & $\begin{array}{l}\text { KEAN Soft Drinks } \\
\text { CPC }\end{array}$ & Protarget AG & $\begin{array}{l}\text { Water preheating } \\
\text { for pasteurization }\end{array}$ & Supply level & Evacuated Tube & 225 & 157.5 & $75 \sim 150$ \\
\hline Latur, India & Mahananda Dairy & Clique Solar & $\begin{array}{l}\text { Steam generation } \\
\text { for pasteurization }\end{array}$ & & Parabolic Trough & 160 & - & 120 \\
\hline $\begin{array}{l}\text { Mangarol, Surat, } \\
\text { India }\end{array}$ & $\begin{array}{l}\text { Tapi Food } \\
\text { Products }\end{array}$ & $\begin{array}{l}\text { Gadhia Solar } \\
\text { Energy Systems } \\
\text { Pvt. Ltd. }\end{array}$ & Water preheating & & $\begin{array}{l}\text { Concentrating } \\
\text { Solar Thermal } \\
\text { Collector }\end{array}$ & 930 & - & - \\
\hline
\end{tabular}


Table 3. Integration scenario in Horticulture Industry [66,71].

\begin{tabular}{|c|c|c|c|c|c|c|}
\hline Installation Site & Company Name & Solar Collector Type & Gross Area $\left(\mathrm{m}^{2}\right)$ & $\begin{array}{c}\text { Installed Thermal } \\
\text { Capacity }\left(K W_{\text {th }}\right)\end{array}$ & Integration Point & Year \\
\hline Jalisco, México & Buenavista Greenhouse & Parabolic Trough Collector & 112 & 36 & Process-level & 2013 \\
\hline Varpelev, Denmark & Østervang Greenhouse & Flat Plate & 15,680 & 9880.0 & Supply Level & 2015 \\
\hline Germany & Kessler Vegetable & Flat Plate & 960 & 672 & Supply Level & 2016 \\
\hline Vienna, Austria & Gärtnerei Bach & $\begin{array}{l}\text { Heating of greenhouse for } \\
\text { agricultural purpose }\end{array}$ & 126 & 88.2 & Supply Level & 2018 \\
\hline $\begin{array}{l}\text { Nibbixwoud, } \\
\text { Netherlands }\end{array}$ & & Flat Plate & 15,000 & 10,500 & - & 2020 \\
\hline Ganzhou, Tibet, China & & Parabolic Trough & 5500 & 3900 & - & 2020 \\
\hline
\end{tabular}




\subsection{Global Integration Scenario in Textile E Leather Industry}

The textile and leather industry is an emerging sector in solar process heat integration. The installed thermal capacity in this sector is $26 \mathrm{MW}_{\text {th }}$ which is $5 \%$ of the globally installed thermal capacity for solar heat integration. Mostly applied operations include retaining, bleaching, and process heating. Tables 4 and 5 presents Textile and Leather industries with solar process heat integration at the supply level and process level respectively.

Table 4. Supply level integration for make-up water heating in existing Textile \& Leather industries [71].

\begin{tabular}{|c|c|c|c|c|c|}
\hline Country & Company & $\begin{array}{c}\text { Solar Collector } \\
\text { Type }\end{array}$ & $\begin{array}{c}\text { Collector Area } \\
\left(\mathrm{m}^{2}\right)\end{array}$ & Temperate Range & $\begin{array}{l}\text { Storage Volume } \\
\left(\mathrm{m}^{3}\right)\end{array}$ \\
\hline Mexico & Guetermann Polygal & Flat Plate & 450 & $55 \sim 85$ & 20 \\
\hline Spain & Harlequin & Flat Plate & 47.15 & - & 5.0 \\
\hline India & Sharman Shawls & Flat Plate & 360 & $>100$ & 8 \\
\hline India & Leo Leather & Flat Plate & 300 & - & 15 \\
\hline Greece & $\begin{array}{l}\text { Tripou-Katsouris } \\
\text { Leather } \\
\text { Treatment Factory }\end{array}$ & & 300 & 15.0 & $48 \sim 84$ \\
\hline
\end{tabular}

Table 5. Process-level integration for make-up water heating in existing Textile \& Leather industries [71].

\begin{tabular}{|c|c|c|c|c|c|c|}
\hline Country & Company & $\begin{array}{c}\text { Solar Collector } \\
\text { Type }\end{array}$ & $\begin{array}{l}\text { Collector } \\
\text { Area }\left(\mathrm{m}^{2}\right)\end{array}$ & $\begin{array}{c}\text { Process } \\
\text { Temperate } \\
\text { Range }\left({ }^{\circ} \mathrm{C}\right)\end{array}$ & $\begin{array}{c}\text { Installed } \\
\text { Thermal } \\
\text { Capacity }\left(\mathrm{KW}_{\mathrm{th}}\right)\end{array}$ & $\begin{array}{c}\text { Storage } \\
\text { Volume }\left(\mathrm{m}^{3}\right)\end{array}$ \\
\hline China & $\begin{array}{c}\text { Heshan Bestway } \\
\text { Leather }\end{array}$ & $\begin{array}{c}\text { Evacuated Tube } \\
\text { Collector }\end{array}$ & 630 & 70 & 441.0 & 60.0 \\
\hline China & Ruyi Textile & $\begin{array}{l}\text { Evacuated Tube } \\
\text { Collector }\end{array}$ & 9903 & 60 & 6932.1 & - \\
\hline Vietnam & $\begin{array}{c}\text { Grammer Solar } \\
\text { Vietnam }\end{array}$ & Air Collector & 480 & & 336.0 & 1 \\
\hline Vietnam & Saigon Tantec & $\begin{array}{l}\text { Evacuated Tube } \\
\text { Collector }\end{array}$ & 1000 & 70 & 700.0 & 70.0 \\
\hline India & $\begin{array}{l}\text { Siddharth } \\
\text { Surgicals }\end{array}$ & $\begin{array}{l}\text { Parabolic Trough } \\
\text { Collector }\end{array}$ & 263 & 110 & 184.1 & - \\
\hline Thailand & $\begin{array}{l}\text { Ayutthaya } \\
\text { tannery }\end{array}$ & $\begin{array}{c}\text { Evacuated Tube } \\
\text { Collector }\end{array}$ & 1890 & 80 & 1323.0 & 80.0 \\
\hline
\end{tabular}

It is interesting to observe that for supply-level integration all projects have flat plate solar collectors, whereas for process-level integration the majority of projects applied evacuated tube solar collectors followed by parabolic trough and air collectors Figure 13 demonstrates the percentage of employed solar collectors in this sector with the highest percentage for flat plate solar collectors. 


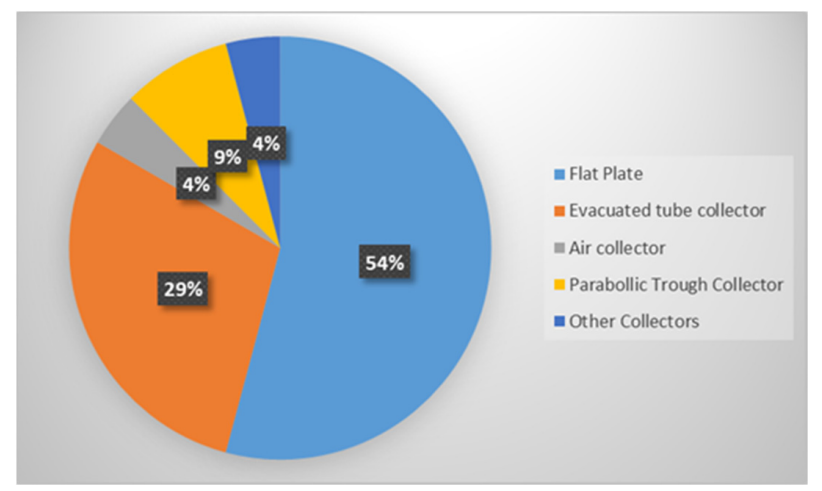

Figure 13. Percentage of applied solar collectors in the Textile and Leather Industry [71].

\subsection{Global Scenario of SHIP Integration in Mining Industries}

The mining industry is another dominating sector for solar thermal integration and has the highest share of installed thermal capacity $(78 \%)$. The main operation includes cleaning, extraction, and process heating. Of the world's largest three SHIP plants, two are in the mining industry (Oman and Chile). There is a total of 14 mining plants currently in operation with eight plants having solar process heat integration at the process level and four plants at the supply level [71]. Figure 14 demonstrates the percentage of SHIP integration on different levels in globally installed mining plants. Table 6 presents the overview of solar process heat in mining industries with process-level integration.

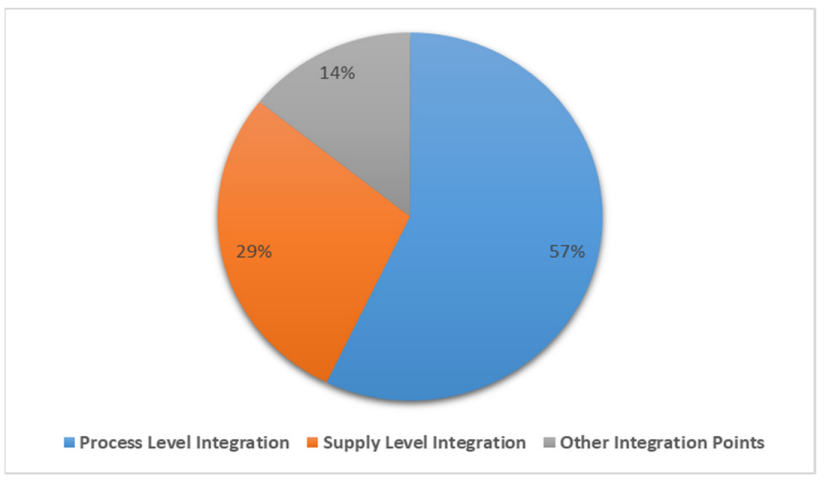

Figure 14. Integration scenario in the mining industry [25,71].

Table 6. SHIP plants in mining industry with process-level integration [25,71].

\begin{tabular}{|c|c|c|c|c|c|c|}
\hline Company Name & Country & $\begin{array}{l}\text { Mining } \\
\text { Material }\end{array}$ & Collector Type & Gross Area & $\begin{array}{l}\text { Power } \\
\left(K_{W_{\text {th }}}\right)\end{array}$ & $\begin{array}{c}\text { Storage } \\
\text { Volume }\left(\mathrm{m}^{3}\right)\end{array}$ \\
\hline Anglo Plat-Middelpunt & South Africa & Platinum & Flat Plate & 180 & 126 & 14.2 \\
\hline $\begin{array}{l}\text { Northam Platinum's } \\
\text { Booysendal Mine }\end{array}$ & South Africa & Platinum & Flat Plate & 192 & 134.4 & 30 \\
\hline $\begin{array}{c}\text { BHP Billiton } \\
\text { Wolwekrans Colliery }\end{array}$ & South Africa & Coal & Flat Plate & 390 & 273 & 40 \\
\hline Anglo Plat-Brakfontein & South Africa & Platinum & Flat Plate & 540 & 378 & 42 \\
\hline Xstrata Elands Mine & South Africa & Platinum & Evacuated Tube & 504 & 352.8 & 60 \\
\hline Hellenic Copper Mines & Cyprus & Copper & Flat Plate & 760 & 532 & 100 \\
\hline Codelco Gabriela Mistral & Chile & Copper & Flat Plate & 39,300 & 27,510 & 4300 \\
\hline Miraah Oman & Oman & & $\begin{array}{c}\text { Parabolic } \\
\text { Trough }\end{array}$ & 630,000 & 300,000 & $\mathrm{~N} / \mathrm{A}$ \\
\hline
\end{tabular}


6.4. Comparison of the Supply Level, Process Level, and Other Point Integration of Solar Industrial Process Heat in Percentile

As discussed in the previous section, a distinction between process level and supply level integration is required for checking the suitability of solar process heat integration in certain industrial sectors. In industries, solar process heat integration generally occurs at the supply level, process level, and other points designed by process suitability. In the previous section, the general integration scenario for several industries (food manufacturing, beverage, agriculture, textile, leather, and mining) was assessed. In this section, the percentage of solar process heat integration at supply level, process-level, and other points is compared as presented in Figure 15.

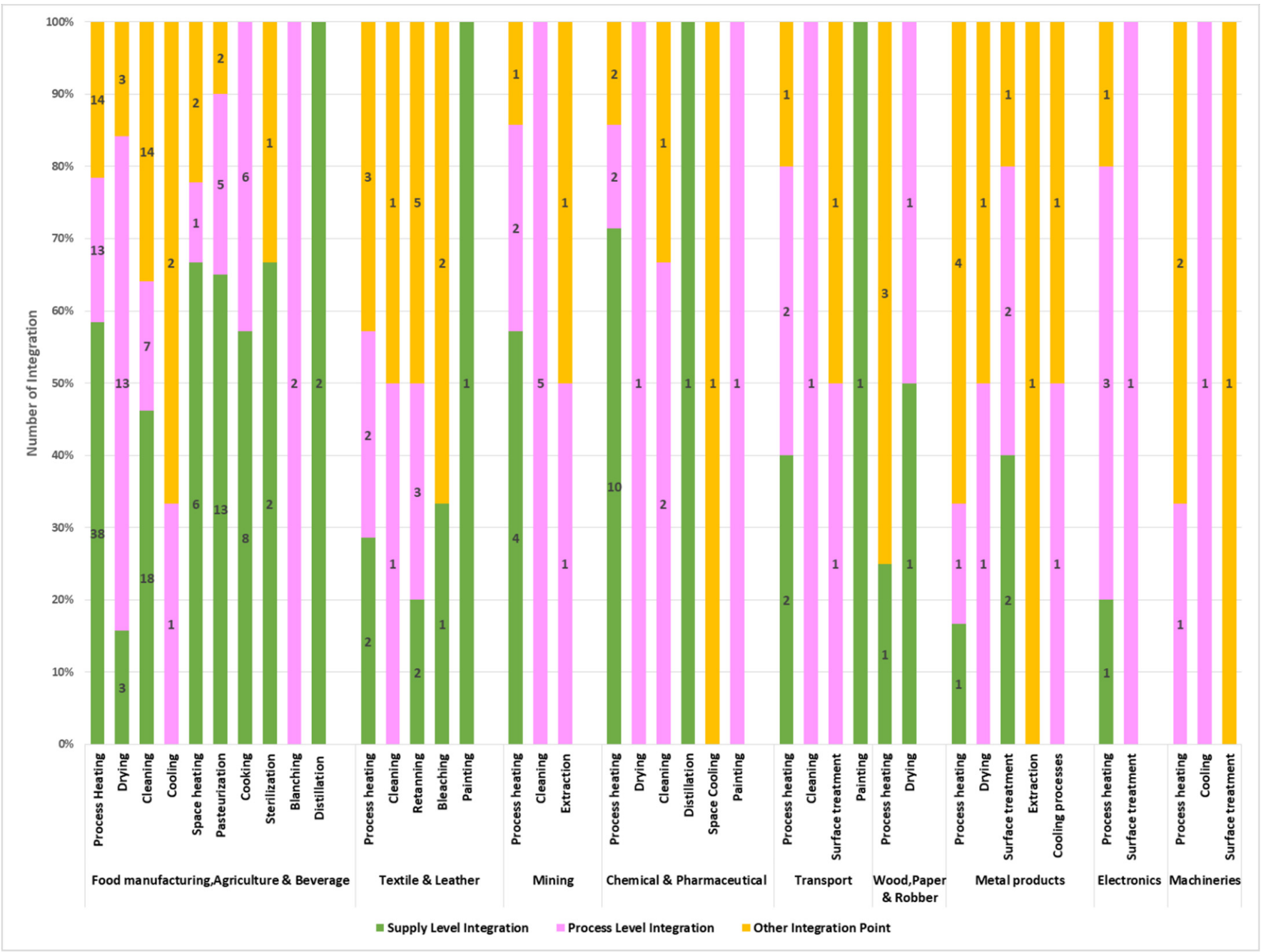

Figure 15. Percentage comparison of integration points for Solar Process Heat in industries [71].

In the food manufacturing, beverage, and agriculture industry, most of the solar process heat integration occurs at the supply level compared to the process level, which is clear from the following figure. Process heating operation (general and other) has the highest number of projects with supply level integration (38 projects), followed by cleaning (18 projects), pasteurization (12 projects), cooking (8 projects), and space heating (6 projects).

However, process-level integration is higher than supply-level integration for the drying operations in the Food industry. The percentage of integration in this sector is $51 \%$ for supply-level integration, $27.3 \%$ for process-level integration, and $22.6 \%$ integration at other points. 
In the textile and leather industry, solar integration at other integration points is slightly higher than the supply level or process-level for the process heating operation. There is no supply-level integration for cleaning operations. For retanning operations, solar integration at the process level and other points is higher than process-level integration. However, the total percentage of the supply-level and process-level integration shares the same value $(26 \%)$ for this sector.

In the mining industry, supply-level integration is higher than both process-level and other integration points for the general and other types of process heating operation. However, for cleaning and extraction operation, all the integrations are at the process level. The percentage of integration for the mining industry is $28.5 \%$ supply-level integration, $57.1 \%$ process-level integration, and $14.25 \%$ integration at other points.

The chemical and pharmaceutical industry is another emerging sector with a total of 21 globally installed projects [71]. In this sector, supply-level integration for process heating operation is much higher (10 projects) compared to process-level and other integration points (four projects). However, there is no supply level integration for drying, cleaning, cooling, and painting operations. The percentage of integration in this industry is $52.3 \%$ supply-level integration, $28.5 \%$ process-level integration, and $19 \%$ integration at other points.

Solar process heat integration in the transport sector is not extensive. In this sector, the process-level integration is a little higher (44\%) than supply-level integration (33\%). For cleaning and surface treatment there is no supply-level integration.

In the field of wood, paper, and rubber products manufacturing, solar heat integration is implemented only in two processes: process heating and drying. For process heating operations, the highest integration occurs at other optimal points followed by supply-level integration. For the drying process, one project has supply-level integration and another project has process-level integration.

In basic/fabricated metal and metal products manufacturing, most of the integrations are at the process level and other points compared to supply-level integration. For drying, extraction, and cooling operations, all solar integrations are at the process level and other optimal points. The percentage of integration in this industry is $18.7 \%$ supply-level integration, $31.3 \%$ process-level integration, and $50 \%$ integration at other points.

In the sector of electronics and machinery manufacturing, solar process heat is integrated only for process heating, surface treatment, and cooling operations.

There is only one project with supply-level integration for process heating operations in the production of electronic equipment. In the industry of machinery manufacturing, all of the solar integrations are at the process level and other integration points.

\section{Integration Scenario from Climatic Perspective}

The implementation of the SHIP system is dependent on relevant climate conditions. The reason for this is that the performance of a solar collector is dependent on weather factors. For a particular process, from appropriate solar collector selection to identifying the suitable integration point depends on the climate of a region. Table 7 demonstrates solar process heat integration in the industries of southern Europe and Mediterranean regions [72]. 
Table 7. Solar process heat integration in southern Europe and Mediterranean countries.

\begin{tabular}{|c|c|c|c|c|c|c|c|}
\hline Region & Location & Provider & Sector & $\begin{array}{l}\text { Collector } \\
\text { Type }\end{array}$ & $\begin{array}{c}\text { Installed } \\
\text { Thermal } \\
\text { Capacity }\left(\mathrm{KW}_{\mathrm{th}}\right)\end{array}$ & $\begin{array}{l}\text { Integration } \\
\text { Point }\end{array}$ & Year \\
\hline \multirow{2}{*}{$\begin{array}{l}\text { South } \\
\text { Europe }\end{array}$} & $\begin{array}{c}\text { Castellbisbal, } \\
\text { Spain }\end{array}$ & Sonnenkraft & Transport & Flat Plate & 357 & Other & 2004 \\
\hline & $\begin{array}{l}\text { Brescia, } \\
\text { Italy }\end{array}$ & - & $\begin{array}{l}\text { Chemical } \\
\text { Industry }\end{array}$ & Flat Plate & 63 & Supply level & 2008 \\
\hline \multirow{5}{*}{ Mediterranean } & Greece & Sunny S.A. & Dairy & Flat Plate & 518 & Supply level & 1999 \\
\hline & Egypt & - & Paint & Flat Plate & 26.88 & Other & 2002 \\
\hline & $\begin{array}{l}\text { Grombalia, } \\
\text { Tunisia }\end{array}$ & $\begin{array}{c}\text { Industrial } \\
\text { Solar GmbH }\end{array}$ & Beverage & $\begin{array}{l}\text { Fresnel } \\
\text { Collector }\end{array}$ & 49.5 & Process-level & 2008 \\
\hline & Jordan & $\begin{array}{c}\text { Industrial } \\
\text { Solar GmbH }\end{array}$ & $\begin{array}{l}\text { Tobacco } \\
\text { Factory }\end{array}$ & $\begin{array}{l}\text { Fresnel } \\
\text { Collector }\end{array}$ & 222 & Supply level & 2015 \\
\hline & Morocco & Rackam & $\begin{array}{l}\text { Dairy } \\
\text { Factory }\end{array}$ & $\begin{array}{l}\text { Parabolic } \\
\text { Trough } \\
\text { Collector }\end{array}$ & 61 & Supply level & 2015 \\
\hline
\end{tabular}

\section{Case Studies of some SHIP Systems from the Literature}

Despite the lack of an established set of principles in the technological context, SHIP projects are carried on worldwide in a wide range of industries and power plants. The method of integration assessment varies from pinch analysis to conceptual designs, as in Baniassadi's case [58]. This section includes a thorough analysis of several design parameters covering case studies of varying industrial sectors from the literature to date (Table 8). Location of the industry, simulation condition, type of processes, solar collector design, the integration point, methodology of integration perusal and the difficulties faced during the project have been summarized to provide future researchers with useful data for better comprehension of the upgraded integration layout. 
Table 8. Design Parameters of Solar Industrial Process Heating Systems from the Literature.

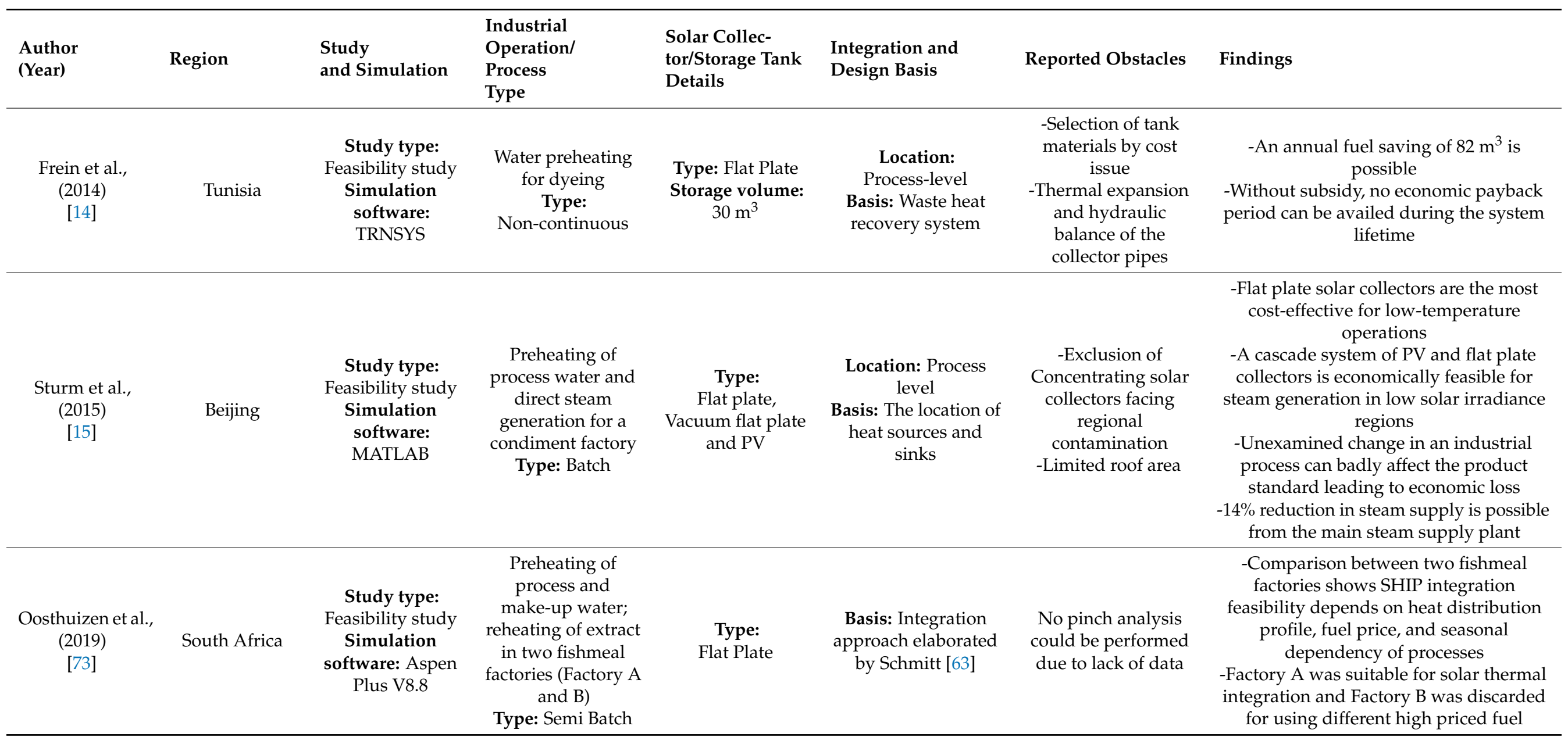


Table 8. Cont.

\begin{tabular}{|c|c|c|c|c|c|c|c|}
\hline $\begin{array}{l}\text { Author } \\
\text { (Year) }\end{array}$ & Region & $\begin{array}{l}\text { Study } \\
\text { and Simulation }\end{array}$ & $\begin{array}{l}\text { Industrial } \\
\text { Operation/ } \\
\text { Process } \\
\text { Type }\end{array}$ & $\begin{array}{l}\text { Solar Collec- } \\
\text { tor/Storage Tank } \\
\text { Details }\end{array}$ & $\begin{array}{l}\text { Integration and } \\
\text { Design Basis }\end{array}$ & Reported Obstacles & Findings \\
\hline $\begin{array}{l}\text { Lugo et al., } \\
\text { (2019) } \\
{[74]}\end{array}$ & Mexico & $\begin{array}{c}\text { Study type: } \\
\text { Development and } \\
\text { analysis of } \\
\text { process } \\
\text { Integration } \\
\text { Simulation } \\
\text { software: } \\
\text { TRNSYS 16 }\end{array}$ & $\begin{array}{l}\text { Designing a solar } \\
\text { water heating } \\
\text { system to run an } \\
\text { industrial } \\
\text { adsorption cooling } \\
\text { system } \\
\text { Type: continuous }\end{array}$ & $\begin{array}{c}\text { Type: } \\
\text { Evacuated tube } \\
\text { Absorber area: } \\
27.5 \mathrm{~m} 2\end{array}$ & - & $\begin{array}{l}\text { The SWHS under } \\
\text { experimentation was } \\
\text { designed based on a } \\
\text { warm climate. So, in } \\
\text { cold environments } \\
\text { the model is less } \\
\text { suitable }\end{array}$ & $\begin{array}{c}\text {-An } 8 \mathrm{~kW} \text { adsorption cooling system can } \\
\text { be operated with an } 86 \% \text { solar fraction } \\
\text {-Income tax benefit can reduce the } \\
\text { reported payback period of } 4 \text { years to } \\
3 \text { years }\end{array}$ \\
\hline $\begin{array}{l}\text { Quijera et al., } \\
\qquad(2013) \\
{[75]}\end{array}$ & $\begin{array}{l}\text { Atlantic, } \\
\text { Basque }\end{array}$ & $\begin{array}{l}\text { Study type: } \\
\text { Development and } \\
\text { analysis of } \\
\text { Integration } \\
\text { methodology }\end{array}$ & $\begin{array}{l}\text { Hot water } \\
\text { production in a fish } \\
\text { canning factory } \\
\text { Type: Batch }\end{array}$ & $\begin{array}{c}\text { Type: } \\
\text { Evacuated tube } \\
\text { Absorber area: } \\
305.2 \mathrm{~m}^{2}\end{array}$ & $\begin{array}{l}\text { Location: Supply } \\
\text { level } \\
\text { Basis: Combined } \\
\text { Pinch analysis and } \\
\text { exergy analysis }\end{array}$ & - & $\begin{array}{l}\text {-Combined exergy and pinch analysis can } \\
\text { and effective solution to SHIP integration } \\
\text { in a dull climate area } \\
\text { - Parallel integration of solar collector and } \\
\text { heat pump provided higher solar fraction } \\
\text { with a smaller collector area }\end{array}$ \\
\hline $\begin{array}{l}\text { Atkins et al., } \\
\qquad(2009) \\
{[11]}\end{array}$ & $\begin{array}{l}\text { Central north } \\
\text { island, } \\
\text { New Zealand }\end{array}$ & $\begin{array}{c}\text { Study type: } \\
\text { Feasibility study }\end{array}$ & $\begin{array}{l}\text { Supplying some of } \\
\text { the process heat } \\
\text { demand in a } \\
\text { powder milk plant } \\
\text { Type: } \\
\text { Non-continuous }\end{array}$ & $\begin{array}{l}\text { Type: } \\
\text { Evacuated tube } \\
\text { Gross area: } \\
1000 \mathrm{~mm}^{2}\end{array}$ & $\begin{array}{c}\text { Location: } \\
\text { Process-level } \\
\text { Basis: Pinch analysis }\end{array}$ & - & $\begin{array}{l}\text {-About } 6.9 \% \text { and } 6.4 \% \text { hot utility can be } \\
\text { supplied by solar energy for constant flow } \\
\text { and constant temperature respectively } \\
\text {-About } 14.4 \% \text { of hot utility demand can be } \\
\text { fulfilled by solar energy considering mass } \\
\text { integration }\end{array}$ \\
\hline
\end{tabular}


Table 8. Cont.

\begin{tabular}{|c|c|c|c|c|c|c|c|}
\hline $\begin{array}{l}\text { Author } \\
\text { (Year) }\end{array}$ & Region & $\begin{array}{l}\text { Study } \\
\text { and Simulation }\end{array}$ & $\begin{array}{l}\text { Industrial } \\
\text { Operation/ } \\
\text { Process } \\
\text { Type }\end{array}$ & $\begin{array}{l}\text { Solar Collec- } \\
\text { tor/Storage Tank } \\
\text { Details }\end{array}$ & $\begin{array}{l}\text { Integration and } \\
\text { Design Basis }\end{array}$ & Reported Obstacles & Findings \\
\hline $\begin{array}{l}\text { Mauthner et al., } \\
\quad(2014) \\
{[77]}\end{array}$ & $\begin{array}{l}\text { Austria, Spain, } \\
\text { and Portugal }\end{array}$ & $\begin{array}{l}\text { Study type: } \\
\text { Integration } \\
\text { solution }\end{array}$ & $\begin{array}{l}\text { Supplying some of } \\
\text { the process heat } \\
\text { demand for } \\
\text { mashing, beer } \\
\text { pasteurization, and } \\
\text { malt drying }\end{array}$ & $\begin{array}{l}\text { Type: Flat Plate } \\
\text { collector }\end{array}$ & $\begin{array}{l}\text { Location: } \\
\text { Process-level }\end{array}$ & - & $\begin{array}{c}\text {-About } 30,45 \text {, and } 20 \% \text { of the process heat } \\
\text { demand can be met with solar energy for } \\
\text { mashing, beer pasteurization, and malt } \\
\text { drying, respectively } \\
\text {-Yearly natural gas savings: } \\
1.570 \text { GWh (Austria) } \\
1.1 \text { GWh(Spain) } \\
\text { 3.670 GWh(Portugal) }\end{array}$ \\
\hline $\begin{array}{l}\text { Bühler et al., } \\
\quad(2016) \\
{[78]}\end{array}$ & Denmark & $\begin{array}{l}\text { Study type: } \\
\text { Integration } \\
\text { solution }\end{array}$ & $\begin{array}{l}\text { Heating of air over } \\
\text { the spray dryer in a } \\
\text { dairy factory }\end{array}$ & $\begin{array}{l}\text { Gross area: } 2000 \\
\mathrm{~m}^{2} \\
\text { Storage volume: } \\
267 \mathrm{~m}^{3}\end{array}$ & $\begin{array}{l}\text { Location: } \\
\text { Process-level } \\
\text { Basis: Annual hourly } \\
\text { global direct and } \\
\text { diffuse solar } \\
\text { radiation }\end{array}$ & $\begin{array}{l}\text { The partial } \\
\text { application of solar } \\
\text { heat can lead to a } \\
\text { reduction in existing } \\
\text { boiler efficiency }\end{array}$ & $\begin{array}{l}\text {-Solar heat integration is economically } \\
\text { feasible for the reported dairy factory in a } \\
\text { region with poor irradiation } \\
\text {-About } 13.6 \% \text { of thermal load can be } \\
\text { supplied by solar energy during the } \\
\text { summer period }\end{array}$ \\
\hline $\begin{array}{l}\text { Anastasovski } \\
(2020) \\
{[79]}\end{array}$ & $\begin{array}{l}\text { Bitola, } \\
\text { Macedonia }\end{array}$ & $\begin{array}{c}\text { Study type: } \\
\text { Feasibility study } \\
\text { Simulation } \\
\text { software: Aspen } \\
\text { HYSYS }\end{array}$ & $\begin{array}{l}\text { Heating of boiler } \\
\text { water for ethanol } \\
\text { production } \\
\text { Type: Mixed Batch } \\
\text { and continuous }\end{array}$ & $\begin{array}{l}\text { Type: Evacuated } \\
\text { tube }\end{array}$ & $\begin{array}{l}\text { Location: Supply } \\
\text { level } \\
\text { Basis: Pinch analysis }\end{array}$ & $\begin{array}{l}\text {-High cost of heat } \\
\text { storage material } \\
\text {-Unpredictable } \\
\text { nature of solar } \\
\text { radiation }\end{array}$ & $\begin{array}{l}\text { Around } 35 \text { to } 40 \% \text { of the process heat } \\
\text { demand can be supplied by solar energy }\end{array}$ \\
\hline $\begin{array}{l}\text { Vargas- } \\
\text { Bautista et al.,(2016) } \\
\quad[80]\end{array}$ & $\begin{array}{l}\text { Monterrey, } \\
\text { México }\end{array}$ & $\begin{array}{l}\text { Study type: } \\
\text { Feasibility study } \\
\text { Simulation } \\
\text { Software: } \\
\text { TRNSYS }\end{array}$ & $\begin{array}{l}\text { Designing a solar } \\
\text { water heating } \\
\text { system as the } \\
\text { reboiler for ethanol } \\
\text { distillation } \\
\text { Type: Continuous }\end{array}$ & $\begin{array}{l}\text { Type: Evacuated } \\
\text { tube and } \\
\text { parabolic trough }\end{array}$ & $\begin{array}{l}\text { Location: Supply } \\
\text { level }\end{array}$ & $\begin{array}{l}\text { Economic } \\
\text { infeasibility in the } \\
\text { project installation } \\
\text { for the highest energy } \\
\text { saving concentration } \\
\text { (5\%) of ethanol }\end{array}$ & $\begin{array}{l}\text { ETCs were found economically feasible } \\
\text { over PTCs but the highest energy savings } \\
\text { were obtained for PTCs }\end{array}$ \\
\hline
\end{tabular}


Table 8. Cont.

\begin{tabular}{|c|c|c|c|c|c|c|c|}
\hline $\begin{array}{l}\text { Author } \\
\text { (Year) }\end{array}$ & Region & $\begin{array}{l}\text { Study } \\
\text { and Simulation }\end{array}$ & $\begin{array}{l}\text { Industrial } \\
\text { Operation/ } \\
\text { Process } \\
\text { Type }\end{array}$ & $\begin{array}{l}\text { Solar Collec- } \\
\text { tor/Storage Tank } \\
\text { Details }\end{array}$ & $\begin{array}{l}\text { Integration and } \\
\text { Design Basis }\end{array}$ & Reported Obstacles & Findings \\
\hline $\begin{array}{l}\text { Winterscheid et al., } \\
\qquad \begin{array}{c}(2017) \\
{[81]}\end{array}\end{array}$ & Germany & $\begin{array}{l}\text { Study type: } \\
\text { Development and } \\
\text { analysis of } \\
\text { Integration } \\
\text { methodology } \\
\text { Simulation } \\
\text { Software: } \\
\text { MATLAB }\end{array}$ & $\begin{array}{l}\text { Running a CHP } \\
\text { plant based district } \\
\text { heating system } \\
\text { using solar energy }\end{array}$ & $\begin{array}{l}\text { Type: Flat plate, } \\
\text { Evacuated tube }\end{array}$ & - & - & $\begin{array}{l}\text {-Solar heat integration to a district } \\
\text { heating network powered by fossil fuel } \\
\text { CHP plants is technically feasible } \\
\text {-System cost vastly depends on the } \\
\text { collector area. }\end{array}$ \\
\hline $\begin{array}{c}\text { El } \\
\text { Mkadmi et al., } \\
(2016) \\
{[12]}\end{array}$ & $\begin{array}{l}\text { Cyprus, France } \\
\text { Morocco }\end{array}$ & $\begin{array}{c}\text { Study type: } \\
\text { Feasibility study }\end{array}$ & $\begin{array}{l}\text { Heating of cleaning } \\
\text { water in a dairy } \\
\text { industry } \\
\text { Type: Continuous }\end{array}$ & $\begin{array}{c}\text { Type: Evacuated } \\
\text { tube } \\
\text { Area: } 400 \mathrm{~m}^{2}\end{array}$ & & & $\begin{array}{l}\text {-About } 89,76 \text {, and } 94 \% \text { thermal energy } \\
\text { demand can be met by the solar thermal } \\
\text { system } \\
\text {-The designed solar thermal system was } \\
\text { found to be economical } \\
\text {-Reported } \mathrm{CO}_{2} \\
\text { savings are: (a) Lyon: } 64.8 \text { ton } \\
\text { (b) Cyprus: } 70.5 \text { ton } \\
\text { (c) Morocco: } 82.67 \text { ton }\end{array}$ \\
\hline $\begin{array}{c}\text { Eiholzer et al., } \\
\text { (2016) } \\
{[16]}\end{array}$ & Scotland & $\begin{array}{l}\text { Study type: } \\
\text { Feasibility study }\end{array}$ & $\begin{array}{l}\text { Preheating of boiler } \\
\text { feed water in a } \\
\text { brewery Plant } \\
\text { Type: Batch }\end{array}$ & $\begin{array}{l}\text { Type: Evacuated } \\
\text { tube and Flat } \\
\text { plate } \\
\text { Storage volume: } \\
\quad 17 \mathrm{~m}^{3}\end{array}$ & $\begin{array}{c}\text { Location: Supply } \\
\text { level } \\
\text { Basis: Muster- } \\
\text { Slawitsch et al., }\end{array}$ & - & $\begin{array}{c}\text {-About } 40 \% \text { of the hot utility demand can } \\
\text { be met by the solar energy } \\
\text {-ETC was chosen over FPC for this } \\
\text { investigation with a payback period of } \\
6.4 \text { years } \\
\text {-Indirect heat recovery was found of high } \\
\text { significance for easy measurements in the } \\
\text { case of breweries }\end{array}$ \\
\hline
\end{tabular}


Table 8. Cont.

\begin{tabular}{|c|c|c|c|c|c|c|c|}
\hline $\begin{array}{l}\text { Author } \\
\text { (Year) }\end{array}$ & Region & $\begin{array}{l}\text { Study } \\
\text { and Simulation }\end{array}$ & $\begin{array}{l}\text { Industrial } \\
\text { Operation/ } \\
\text { Process } \\
\text { Type }\end{array}$ & $\begin{array}{l}\text { Solar Collec- } \\
\text { tor/Storage Tank } \\
\text { Details }\end{array}$ & $\begin{array}{l}\text { Integration and } \\
\text { Design Basis }\end{array}$ & Reported Obstacles & Findings \\
\hline $\begin{array}{l}\text { Guillaume et al., } \\
\qquad(2019) \\
{[82]}\end{array}$ & Switzerland & $\begin{array}{l}\text { Study type: } \\
\text { Feasibility study } \\
\text { and integration } \\
\text { solution } \\
\text { Simulation } \\
\text { software: } \\
\text { Polysun }\end{array}$ & $\begin{array}{l}\text { Drying process in a } \\
\text { pharmaceutical } \\
\text { company }\end{array}$ & $\begin{array}{l}\text { Gross area: } \\
1060 \mathrm{~m}^{2} \\
\text { Storage volume: } \\
50 \mathrm{~m}^{3} \text { and } 30 \mathrm{~m}^{3}\end{array}$ & $\begin{array}{c}\text { Location: } \\
\text { Process-level } \\
\text { Basis: } \\
\text { IEA SHC Task } \\
49 \text { Integration } \\
\text { guidelines }\end{array}$ & Limited roof area & $\begin{array}{l}\text {-About } 15 \% \text { of thermal energy demand } \\
\text { can be met with a solar thermal system } \\
\text { for the Swiss pharmaceutical sector } \\
\text {-About } 38 \% \text { thermal energy demand of } \\
\text { the selected case study can be provided } \\
\text { by the solar thermal system } \\
\text {-Solar incentives and } \mathrm{CO}_{2} \text { taxes are } \\
\text { required to make the project economically } \\
\text { feasible }\end{array}$ \\
\hline $\begin{array}{l}\text { Frey et al., } \\
\text { (2015) } \\
\text { [83] }\end{array}$ & Germany & $\begin{array}{c}\text { Study type: } \\
\text { General overview }\end{array}$ & $\begin{array}{l}\text { Hot water } \\
\text { production for a } \\
\text { textile company }\end{array}$ & $\begin{array}{c}\text { Type: Parabolic } \\
\text { trough collectors } \\
\quad \text { (PTCs) } \\
\text { Storage volume: } \\
10 \mathrm{~m}^{3} \text { to } 70 \mathrm{~m}^{3}\end{array}$ & - & $\begin{array}{l}\text {-Limited roof area } \\
\text { - Imperfect tacking } \\
\text { mechanism of the } \\
\text { solar collector } \\
\text {-Instability of } \\
\text { weather conditions }\end{array}$ & $\begin{array}{l}\text { - Solar collector yield was } 21.8 \mathrm{MWh} \text { with } \\
\text { a System efficiency: } 27.8 \% \\
\text {-C.O.P (Electrical): } 10.7 .\end{array}$ \\
\hline
\end{tabular}


Table 8. Cont.

\begin{tabular}{|c|c|c|c|c|c|c|c|}
\hline $\begin{array}{l}\text { Author } \\
\text { (Year) }\end{array}$ & Region & $\begin{array}{l}\text { Study } \\
\text { and Simulation }\end{array}$ & $\begin{array}{l}\text { Industrial } \\
\text { Operation/ } \\
\text { Process } \\
\text { Type }\end{array}$ & $\begin{array}{l}\text { Solar Collec- } \\
\text { tor/Storage Tank } \\
\text { Details }\end{array}$ & $\begin{array}{l}\text { Integration and } \\
\text { Design Basis }\end{array}$ & Reported Obstacles & Findings \\
\hline $\begin{array}{l}\text { Murray et al., } \\
\quad(2016) \\
{[85]}\end{array}$ & Curicó, Chile & $\begin{array}{l}\text { Study type: } \\
\text { Feasibility study } \\
\text { Simulation } \\
\text { software: } \\
\text { TRNSYS }\end{array}$ & $\begin{array}{l}\text { Running an } \\
\text { absorption chiller } \\
\text { using solar and } \\
\text { biomass energy for } \\
\text { a Winemaking } \\
\text { industry } \\
\text { Type: Continuous }\end{array}$ & $\begin{array}{l}\text { Type: Flat plate } \\
\text { Area: } 250 \mathrm{~m}^{2} \text { to } \\
1000 \mathrm{~m}^{2} \\
\text { Storage Tanks: } \\
60 \mathrm{~m}^{3}, 20 \mathrm{~m}^{3} \text { and } \\
30 \mathrm{~m}^{3}\end{array}$ & - & $\begin{array}{l}\text { The collector field } \\
\text { area was much more } \\
\text { than the requirement } \\
\text { for the winter season }\end{array}$ & $\begin{array}{c}\text {-About } 25 \% \text { and } 30-50 \% \text { thermal load can } \\
\text { be supplied by the proposed system } \\
\text { during summer and winter time } \\
\text { respectively } \\
\text {-The authors suggested waste products as } \\
\text { fuel instead of pellets for economic } \\
\text { savings }\end{array}$ \\
\hline $\begin{array}{l}\text { Berger et al., } \\
\quad(2011) \\
{[86]}\end{array}$ & Jordan & $\begin{array}{l}\text { Study type: } \\
\text { Overview }\end{array}$ & $\begin{array}{l}\text { Saturated steam } \\
\text { generation for pill } \\
\text { drying in a } \\
\text { pharmaceutical } \\
\text { company } \\
\text { Type: Continuous }\end{array}$ & $\begin{array}{l}\text { Type: Fresnel } \\
\text { collector field } \\
\text { Aperture Area: } \\
\quad 396 \mathrm{~m}^{2}\end{array}$ & - & - & $\begin{array}{l}100 \% \text { solar fraction is achievable during } \\
\text { daytime thus eliminating the use of } \\
\text { conventional steam boiler }\end{array}$ \\
\hline $\begin{array}{l}\text { Pathak et al., } \\
\qquad(2017) \\
\text { [87] }\end{array}$ & Nagpur, India & $\begin{array}{l}\text { Study type: } \\
\text { Overview }\end{array}$ & $\begin{array}{l}\text { Component } \\
\text { Washing in an } \\
\text { Automobile } \\
\text { Industry }\end{array}$ & $\begin{array}{l}\text { Type: Compound } \\
\text { parabolic } \\
\text { concentrators } \\
\text { (CPC) } \\
\text { Gross Area: } \\
442 \mathrm{~m}^{2}\end{array}$ & $\begin{array}{c}\text { Location: } \\
\text { Process-level }\end{array}$ & $\begin{array}{l}\text { - Maintaining the } \\
\text { process temperature } \\
\text {-Risks with rooftop } \\
\text { installations }\end{array}$ & $\begin{array}{c}\text {-The solar system is seamlessly integrated } \\
\text { with the existing system } \\
\text {-The savings in electricity and } \mathrm{CO}_{2} \\
\text { emission were } 1,75,000 \mathrm{kWh} \text { and } 164 \mathrm{MT} \\
\text { per year respectively } \\
\text {-Payback period was } 4 \text { to } 5 \text { years }\end{array}$ \\
\hline $\begin{array}{l}\text { Bolognese et al., } \\
\qquad(2020) \\
{[88]}\end{array}$ & Italy & $\begin{array}{c}\text { Study type: } \\
\text { Integration } \\
\text { solution } \\
\text { Simulation } \\
\text { software: } \\
\text { Dymola-Dassault } \\
\text { Systems along } \\
\text { with MATLAB }\end{array}$ & $\begin{array}{l}\text { Preheating of the } \\
\text { boiler return water } \\
\text { for pasta drying } \\
\text { Type: Continuous }\end{array}$ & $\begin{array}{c}\text { Type: (a) } \\
\text { Parabolic trough } \\
\text { collector, (b) } \\
\text { Linear Fresnel } \\
\text { reflector (LFR) } \\
\text { and } \\
\text { (c) Compound } \\
\text { parabolic } \\
\text { collector } \\
\text { (CPC) }\end{array}$ & $\begin{array}{c}\text { Location: Supply } \\
\text { level }\end{array}$ & - & $\begin{array}{c}\text { Parabolic trough collector field can } \\
\text { supply about } 23 \% \text { of the energy demand } \\
\text { on a weekly basis with a payback period } \\
\text { of } 9 \text { years }\end{array}$ \\
\hline
\end{tabular}


Table 8. Cont.

\begin{tabular}{|c|c|c|c|c|c|c|c|}
\hline $\begin{array}{l}\text { Author } \\
\text { (Year) }\end{array}$ & Region & $\begin{array}{l}\text { Study } \\
\text { and Simulation }\end{array}$ & $\begin{array}{l}\text { Industrial } \\
\text { Operation/ } \\
\text { Process } \\
\text { Type }\end{array}$ & $\begin{array}{l}\text { Solar Collec- } \\
\text { tor/Storage Tank } \\
\text { Details }\end{array}$ & $\begin{array}{l}\text { Integration and } \\
\text { Design Basis }\end{array}$ & Reported Obstacles & Findings \\
\hline $\begin{array}{l}\text { Crespo et al., } \\
\qquad(2019) \\
{[89]}\end{array}$ & $\begin{array}{l}\text { Diaguitas, } \\
\text { Coquimbo, } \\
\text { Chile }\end{array}$ & $\begin{array}{l}\text { Study type: } \\
\text { Feasibility study } \\
\text { Simulation } \\
\text { software: } \\
\text { TRNSYS } 18\end{array}$ & $\begin{array}{l}\text { Heating of process } \\
\text { water in a Brewery } \\
\text { factory } \\
\text { Type: Batch }\end{array}$ & $\begin{array}{l}\text { Type: } \\
\text { Flat plat and } \\
\text { Photovoltaic } \\
\text { plant }\end{array}$ & $\begin{array}{c}\text { Location: } \\
\text { Process-level } \\
\text { Integration analysis: } \\
\text { Method by } \\
\text { Lauterbach et.al [90] }\end{array}$ & & $\begin{array}{c}\text {-About } 79 \% \text { of process hot water and } \\
7 \text { years of payback period can be attained } \\
\text { by integrating flat plate collector field } \\
\text { with a storage tank } \\
\text {-With the photovoltaic plant it is possible } \\
\text { to achieve about } 38.5 \% \text { of the electricity } \\
\text { demand with a payback period of around } \\
4 \text { years }\end{array}$ \\
\hline $\begin{array}{l}\text { Carnevale et al., } \\
\qquad(2011) \\
{[91]}\end{array}$ & Prato, Italy & $\begin{array}{c}\text { Study type: } \\
\text { Feasibility study } \\
\text { Simulation } \\
\text { software: } \\
\text { TRNSYS }\end{array}$ & $\begin{array}{c}\text { Heating of the } \\
\text { diathermic oil loop } \\
\text { Textile factory } \\
\text { Type: } \\
\text { Noncontinuous }\end{array}$ & $\begin{array}{c}\text { Type: } \\
\text { Parabolic solar } \\
\text { Area: } 545 \mathrm{~m}^{2}\end{array}$ & $\begin{array}{c}\text { Location: Supply } \\
\text { level }\end{array}$ & $\begin{array}{l}\text { Lack of factory data } \\
\text { to find the natural } \\
\text { gas consumption by } \\
\text { the boiler }\end{array}$ & $\begin{array}{l}\text {-About } 40 \% \text { fuel saving is possible by one } \\
\text { solar collector } \\
\text {-Excessive installation costs of solar } \\
\text { collectors superseded the fuel savings }\end{array}$ \\
\hline
\end{tabular}




\section{Discussion}

Solar process heat integration has vast possibilities to reduce fossil fuel consumption in industries, leading to economic, environmental, and various other advantages. SHIP-based industries are increasing rapidly, mostly without any subsidies. However, the successful integration of solar heat is a critical subject that depends on the type of industrial processes, equipment, system layouts, climate, the point of integration and other parameters. Supplylevel integration requires less effort and data accuracy than process-level integration. However, the set temperatures of the solar heating system are quite high for supply-level integration starting from $100{ }^{\circ} \mathrm{C}$, and can exceed $200^{\circ} \mathrm{C}$. As a result, collector efficiency is reduced for supply-level integration making it best suited for high solar irradiation regions. On the other hand, process-level integration is best suited for a low set temperature of the solar heating system. However, much effort is required for implementing solar heat integration at the process level.

The present analysis provides the following findings.

- The overall rate of solar process heat integration at the supply level is greater than the process level for food manufacturing, agriculture and the beverage industry, the chemical \& pharmaceutical industry, wood, rubber and plastic manufacturing industries.

- The overall rate of solar process heat integration at the process level is higher than the supply level in the industrial sector of mining, basic and fabricated metal manufacturing, electrical equipment, and machinery manufacturing.

- The most common operations for solar process heat integration in almost all industries are process heating (general and other types), drying, and cleaning.

- For general and other types of process heating operations, supply level integration has the highest percentile for almost all considered industries (food, chemical, mining, transport, wood, and rubber) except for the metal, electronics, and machinery manufacturing industries.

- For drying operations, process-level integration is greater for almost all of the associated industries (food, textile, chemical, transport, and metal manufacturing) except for the wood, rubber, and plastic manufacturing industries.

- For cleaning operations, supply-level integration is higher than process-level integration for the food industry. However, process-level integration is higher than supply level integration for the chemical, mining, textile, and transport industry.

- For future research, along with supply level integration, emphasis should be put on simplifying the integration concept at the process level and other optimal points with the purpose of reducing the investment cost, effort and making the SHIP system more efficient. Categorization of industries and unit operations on the basis of integration points should be investigated to understand and access the most feasible and attractive solution for solar process heat integration.

\section{Conclusions}

Considering the environment, economics, and technological development, proper utilization of renewable sources of energy in the industrial sector is both logical and congruent. Beginning in the late 1970s, although solar process heat integration for industrial purposes had not yet made any breakthrough, the concept was continuously gaining research interest and spreading steadily throughout industries worldwide. Solar process heat integration in industries has the potential for creating a carbon-free environment, but the process is at its early stage. The analysis in this review clearly shows that successful SHIP projects are more likely to be achieved by deep analysis of integration point selection among other 1 factors such as development of the solar collector and use in suitable industries. As process-level integration is relatively arduous, it might discourage solar integration. So, future research has the full scope to target the evaluation of more feasible integration arrangements at the process level. The efficiency of supply-level integration can be enhanced by optimizing the heat distribution network. Finally, the results obtained in this paper can be applied in planning and developing both existing and new integration 
strategies in industries worldwide. In addition, the data in this paper can assist in ongoing research towards successful actualization of SHIP projects for a zero-carbon society to diminish the dependence on gradually diminishing fossil fuels.

Author Contributions: Conceptualization: N.T., S.H.F. and M.A.P.M.; methodology: N.T., S.H.F.; software: M.R.H.; formal analysis: N.T., M.R.H. and S.G., writing—original draft preparation: N.T.; writing-review and editing: S.H.F., M.R.H., S.G.; supervision: M.A.P.M. All authors have read and agreed to the published version of the manuscript.

Funding: This research received no external funding.

Institutional Review Board Statement: Not applicable.

Informed Consent Statement: Not applicable.

Data Availability Statement: The authors confirm that the data supporting the findings of this study are available within the article.

Conflicts of Interest: The authors declare no conflict of interest.

\section{References}

1. Patil, P.G.; Srivastava, A. State-of-the-Art of Solar Thermal Industrial Process Heat Technologies for Use In Developing Countries. In Energy Developments: New Forms, Renewables, Conservation; Pergamon Press: Oxford, UK, 1984; pp. 577-583.

2. Weiss, W.; Spörk-Dür, M. Solar Heat Worldwide. 2021. Available online: https://www.iea-shc.org/solar-heat-worldwide (accessed on 10 January 2022).

3. Sharma, A.K.; Sharma, C.; Mullick, S.C.; Kandpal, T.C. Solar industrial process heating: A review. Renew. Sustain. Energy Rev. 2017, 78, 124-137. [CrossRef]

4. EIA. Use of Energy in Industry-U.S. Energy Information Administration (EIA). Energy Use in Industry; 2018. Available online: https:/ / www.eia.gov/energyexplained/use-of-energy/industry.php (accessed on 8 March 2021).

5. Conti, J.; Holtberg, P.; Diefenderfer, J.; LaRose, A.; Turnure, J.T.; Westfall, L. International Energy Outlook 2016 With Projections to 2040; USDOE Energy Information Administration (EIA): Washington, DC, USA, 2016; Volume 0408, pp. 113-126. [CrossRef]

6. IRENA. Solar heat for industrial processes. Technol. Briefs 2015, 37, 1-36. [CrossRef]

7. When Will Fossil Fuels Run Out? Octopus Energy. Available online: https:/ / octopus.energy/blog/when-will-fossil-fuels-runout/ (accessed on 10 April 2021).

8. Farjana, S.H.; Huda, N.; Mahmud, M.A.P.; Saidur, R. Solar process heat in industrial systems-A global review. Renew. Sustain. Energy Rev. 2018, 82, 2270-2286. [CrossRef]

9. Kumar, L.; Hasanuzzaman, M.; Rahim, N.A. Global advancement of solar thermal energy technologies for industrial process heat and its future prospects: A review. Energy Convers. Manag. 2019, 195, 885-908. [CrossRef]

10. Quijera, J.A.; Alriols, M.G.; Labidi, J. Integration of a solar thermal system in canned fish factory. Appl. Therm. Eng. 2014, 70, 1062-1072. [CrossRef]

11. Atkins, M.J.; Walmsley, M.R.W.; Morrison, A.S. Integration of solar thermal for improved energy efficiency in low-temperaturepinch industrial processes. Energy 2010, 35, 1867-1873. [CrossRef]

12. El Mkadmi, C.; Wahed, A. Optimization of a solar thermal system for low temperature industrial heating process. In Proceedings of the 2016 International Renewable and Sustainable Energy Conference (IRSEC), Marrakech, Morocco, 14-17 November 2016; pp. 313-319. [CrossRef]

13. Kalogirou, S. The potential of solar industrial process heat applications. Appl. Energy 2003, 76, 337-361. [CrossRef]

14. Frein, A.; Calderoni, M.; Motta, M. Solar thermal plant integration into an industrial process. Energy Procedia 2014, $48,1152-1163$. [CrossRef]

15. Sturm, B.; Meyers, S.; Zhang, Y.; Law, R.; Valencia, E.J.S.; Bao, H.; Wang, Y.; Chen, H. Process intensification and integration of solar heat generation in the Chinese condiment sector-A case study of a medium sized Beijing based factory. Energy Convers. Manag. 2015, 106, 1295-1308. [CrossRef]

16. Eiholzer, T.; Olsen, D.; Hoffmann, S.; Sturm, B.; Wellig, B. Integration of a solar thermal system in a medium-sized brewery using pinch analysis: Methodology and case study. Appl. Therm. Eng. 2017, 113, 1558-1568. [CrossRef]

17. Kumar, L.; Hasanuzzaman, M.; Rahim, N.A.; Islam, M.M. Modeling, simulation and outdoor experimental performance analysis of a solar-assisted process heating system for industrial process heat. Renew. Energy 2021, 164, 656-673. [CrossRef]

18. Wüest, T.; Grobe, L.O.; Luible, A. An innovative façade element with controlled solar-thermal collector and storage. Sustainability 2020, 12, 5281. [CrossRef]

19. Znaczko, P.; Szczepanski, E.; Kaminski, K.; Chamier-Gliszczynski, N.; Kukulski, J. Experimental diagnosis of the heat pipe solar collector malfunction. A case study. Energies 2021, 14, 3050. [CrossRef]

20. Kuczynski, W.; Kaminski, K.; Znaczko, P.; Chamier-Gliszczynski, N.; Piatkowski, P. On the correlation between the geometrical features and thermal efficiency of flat-plate solar collectors. Energies 2021, 14, 261. [CrossRef] 
21. Ding, D.; He, W.; Liu, C. Mathematical modeling and optimization of vanadium-titanium black ceramic solar collectors. Energies 2021, 14, 618. [CrossRef]

22. Farjana, S.H.; Huda, N.; Mahmud, M.A.P.; Saidur, R. Solar industrial process heating systems in operation-Current SHIP plants and future prospects in Australia. Renew. Sustain. Energy Rev. 2018, 91, 409-419. [CrossRef]

23. Farjana, S.H.; Huda, N.; Mahmud, M.A.P.; Lang, C. Life-cycle assessment of solar integrated mining processes: A sustainable future. J. Clean. Prod. 2019, 236, 117610. [CrossRef]

24. Farjana, S.H.; Mahmud, M.A.P.; Huda, N. Solar process heat integration in lead mining process. Case Stud. Therm. Eng. 2020, 22, 100768. [CrossRef]

25. Sarbu, I.; Sebarchievici, C. Solar Heating and Cooling Systems; Academic Press: Cambridge, MA, USA, 2016.

26. Kutscher, C.F.; Davenport, R.L.; Dougherty, D.A.; Gee, R.C.; Masterson, P.M.; May, E.K. Design Approaches for Solar Industrial Process Heat Systems. J. Sol. Energy Eng. 1985, 107, 363. [CrossRef]

27. Hess, S. Solar thermal process heat (SPH) generation. In Renewable Heating and Cooling; Elsevier: Amsterdam, The Netherlands, 2016; pp. 41-66.

28. Tyagi, V.V.; Kaushik, S.C.; Tyagi, S.K. Advancement in solar photovoltaic/thermal (PV/T) hybrid collector technology. Renew. Sustain. Energy Rev. 2012, 16, 1383-1398. [CrossRef]

29. Barone, G.; Buonomano, A.; Forzano, C.; Palombo, A. Solar Thermal Collectors; Elsevier Inc.: Amsterdam, The Netherlands, 2019.

30. Sabiha, M.A.; Saidur, R.; Mekhilef, S.; Mahian, O. Progress and latest developments of evacuated tube solar collectors. Renew. Sustain. Energy Rev. 2015, 51, 1038-1054. [CrossRef]

31. Häberle, A. Concentrating solar technologies for industrial process heat and cooling. In Concentrating Solar Power Technology; Woodhead Publishing: Sawston, UK, 2012; pp. 602-619. [CrossRef]

32. Lauterbach, C.; Schmitt, B.; Jordan, U.; Vajen, K. The potential of solar heat for industrial processes in Germany. Renew. Sustain. Energy Rev. 2001, 16, 5121-5130. [CrossRef]

33. McDonald, A.G.; Magande, H.L. Fundamentals of Heat Exchanger Design. In Introduction to Thermo-Fluids Systems Design; John Wiley\&Sons, Ltd.: Hoboken, NJ, USA, 2012.

34. Smith, P. Piping Materials Guide; Elsevier: Amsterdam, The Netherlands, 2005.

35. Moya, E.Z. Parabolic-trough concentrating solar power (CSP) systems. In Concentrating Solar Power Technology; Woodhead Publishing: Sawston, UK, 2012; pp. 197-239.

36. Sarbu, I.; Sebarchievici, C. A comprehensive review of thermal energy storage. Sustainability 2018, 10, 191. [CrossRef]

37. Gil, A.; Medrano, M.; Martorell, I.; Lázarob, A.; Dolado, P.; Zalba, B.; Cabeza, L.F. State of the art on high temperature thermal energy storage for power generation. Part 1-Concepts, materials and modellization. Renew. Sustain. Energy Rev. 2010, 14, 31-55. [CrossRef]

38. Sarkar, J.; Bhattacharyya, S. Application of graphene and graphene-based materials in clean energy-related devices Minghui. Arch. Thermodyn. 2012, 33, 23-40. [CrossRef]

39. Dincer, I.; Rosen, M.A. Industrial Heating and Cooling Systems. In Exergy Analysis of Heating, Refrigerating and Air Conditioning; Elsevier: Amsterdam, The Netherlands, 2015; pp. 99-129. [CrossRef]

40. Industrial Heat Pumps for Steam and Fuel Savings. 2003. Available online: http://www1.eere.energy.gov/manufacturing/tech_ assistance/pdfs/heatpump.pdf (accessed on 9 January 2022).

41. Zhang, T.; Yang, H. High efficiency plants and building integrated renewable energy systems: Building-integrated photovoltaics (BIPV). In Handbook of Energy Efficiency in Buildings: A Life Cycle Approach; Elsevier: Amsterdam, The Netherlands, 2018; pp. 441-595. [CrossRef]

42. Wang, Z.; Huang, Z.; Zheng, S.; Zhao, X. Solar Water Heaters. In A Comprehensive Guide to Solar Energy Systems; Elsevier Inc.: Amsterdam, The Netherlands, 2018; pp. 111-125.

43. Cresko, J.; Shenoy, D.; Liddell, H.P.H.; Sabouni, R. Innovating Clean Energy Technologies in Advanced Manufacturing Technology Assessments; Quadrennial Technology, U.S. Department of Energy: Washington, DC, USA, 2015.

44. Baer, D.; Gordon, J.M.; Zarmi, Y. Design and optimization of solar steam systems for constant load applications. Sol. Energy 1985, 35, 137-151. [CrossRef]

45. Tibasiima, N.; Okullo, A. Energy Targeting for a Brewing Process Using Pinch Analysis. Energy Power Eng. 2017, 9, 11-21. [CrossRef]

46. Linnhoff, B.; Flower, J.R. Synthesis of Heat Exchanger. AlChE J. 1978, 24, 107-119.

47. Kemp, I.; Deakin, A. The cascade analysis for energy and process integration of batch processes. I: Calculation of energy targets. Chem. Eng. Res. Des. 1989, 67, 495-509.

48. Kemp, I.C.; MacDonald, E.K. Application of pinch technology to separation, reaction and batch processes. In IChemE Symposium Series; IChemE: Rugby, UK, 1988; pp. 239-257.

49. Crump, P.R.; Greenwood, D.V. Understanding Process Integration II; CRC Press: Boca Raton, FL, USA, 1988.

50. Nemet, A.; Klemeš, J.J.; Varbanov, P.S.; Kravanja, Z. Methodology for maximising the use of renewables with variable availability. Energy 2012, 44, 29-37. [CrossRef]

51. Perry, S. Total Site Methodology. In Handbook of Process Integration (PI): Minimisation of Energy and Water Use, Waste and Emissions; Woodhead Publishing: Sawston, UK, 2013; pp. 201-225. 
52. Varbanov, P.S. Extending total site methodology to address varying energy supply and demand. In Handbook of Process Integration (PI); Elsevier: Amsterdam, The Netherlands, 2013; pp. 226-261.

53. Chew, K.H.; Klemeš, J.J.; Alwi, S.R.W.; Abdul Manan, Z. Industrial implementation issues of total site heat integration. Appl. Therm. Eng. 2013, 61, 17-25. [CrossRef]

54. Matsuda, K.; Hirochi, Y.; Tatsumi, H.; Shire, T. Applying heat integration total site based pinch technology to a large industrial area in Japan to further improve performance of highly efficient process plants. Energy 2009, 34, 1687-1692. [CrossRef]

55. Hackl, R.; Harvey, S. From heat integration targets toward implementation-A TSA (total site analysis)-based design approach for heat recovery systems in industrial clusters. Energy 2015, 90, 163-172. [CrossRef]

56. Abdelouadoud, Y.; Lucas, E.; Krummenacher, P.; Olsen, D.; Wellig, B. Batch process heat storage integration: A simple and effective graphical approach. Energy 2019, 185, 804-818. [CrossRef]

57. Nemet, A.; Kravanja, Z.; Klemeš, J.J. Integration of solar thermal energy into processes with heat demand. Clean Technol. Environ. Policy 2012, 14, 453-463. [CrossRef]

58. Baniassadi, A.; Momen, M.; Amidpour, M. A new method for optimization of Solar Heat Integration and solar fraction targeting in low temperature process industries. Energy 2015, 90, 1674-1681. [CrossRef]

59. Baniassadi, A.; Momen, M.; Amidpour, M.; Pourali, O. Modeling and design of solar heat integration in process industries with heat storage. J. Clean. Prod. 2018, 170, 522-534. [CrossRef]

60. Abdelhady, F.; Bamufleh, H.; El-Halwagi, M.M.; Ponce-Ortega, J.M. Optimal design and integration of solar thermal collection, storage, and dispatch with process cogeneration systems. Chem. Eng. Sci. 2015, 136, 158-167. [CrossRef]

61. Rashid, K.; Safdarnejad, S.M.; Powell, K.M. Process intensification of solar thermal power using hybridization, flexible heat integration, and real-time optimization. Chem. Eng. Process._Process Intensif. 2019, 139, 155-171. [CrossRef]

62. Schmitt, B. Classification of Industrial Heat Consumers for Integration of Solar Heat. Energy Procedia 2016, 91, 650-660. [CrossRef]

63. Schmitt, B.; Lauterbach, C.; Vajen, K. Investigation of selected solar process heat applications regarding their technical requirments for system integration. In Proceedings of the ISES Solar World Congress, Kassel, Germany, 28 August-2 September 2011.

64. IEA SHC Task 49. Solar Process Heat for Production and Advanced Applications for Collectors Used in Solar Process Heat. No. May, 2016. Available online: https:/ / task49.iea-shc.org/ (accessed on 8 January 2022).

65. Solarthermalworld. Available online: https://www.solarthermalworld.org/ (accessed on 24 December 2021).

66. China Keeps Top Spot for Industrial Solar Heat—Solar Payback. Available online: https://www.solar-payback.com/china-keepstop-spot-for-industrial-solar-heat/ (accessed on 24 December 2021).

67. Ramos, C.; Ramirez, R.; Beltran, J. Potential Assessment in Mexico for Solar Process Heat Applications in Food and Textile Industries. Energy Procedia 2014, 49, 1879-1884. Available online: https://www.sciencedirect.com/science/article/pii/S1876610 214006535 (accessed on 29 December 2021). [CrossRef]

68. Eswara, A.R.; Ramakrishnarao, M. Solar energy in food processing-A critical appraisal. J. Food Sci. Technol. 2013, 50, 209-227. [CrossRef] [PubMed]

69. Ismail, M.; Yunus, N.; Hashim, H. Integration of Solar Heating Systems for Low-Temperature Heat Demand in Food Processing Industry-A Review. Renew. Sustain. Energy Rev. 2021, 147, 111192. Available online: https:/ /www.sciencedirect.com/science/ article/pii/S1364032121004809 (accessed on 29 December 2021). [CrossRef]

70. Installed I | Projects. Available online: http:/ / www.cshindia.in/installedprojects.html (accessed on 24 December 2021).

71. Home ISolar Heat for Industrial Processes (SHIP) Plants Database. Available online: http://ship-plants.info/ (accessed on 1 June 2021).

72. Cottret, N. Technical Study Report on Olar Heat for Industrial Processes (SHIP) State of the Art in the Mediterranean Region; Observatoire Méditerranéen de l'Energie: Nanterre, France, 2007.

73. Oosthuizen, D.; Goosen, N.J.; Hess, S. Solar thermal process heat in fishmeal production: Prospects for two South African fishmeal factories. J. Clean. Prod. 2020, 253, 119818. [CrossRef]

74. Lugo, S.; García-Valladares, O.; Best, R.; Hernández, J.; Hernández, F. Numerical simulation and experimental validation of an evacuated solar collector heating system with gas boiler backup for industrial process heating in warm climates. Renew. Energy 2019, 139, 1120-1132. [CrossRef]

75. Quijera, J.A.; García, A.; Alriols, M.G.; Labidi, J. Heat integration options based on pinch and exergy analyses of a thermosolar and heat pump in a fish tinning industrial process. Energy 2013, 55, 23-37. [CrossRef]

76. Allouhi, A.; Agrouaz, Y.; Benzakour Amine, M.; Rehman, S.; Buker, M.S.; Kousksou, T.; Jamil, A.; Benbassou, A. Design optimization of a multi-temperature solar thermal heating system for an industrial process. Appl. Energy 2017, 206, 382-392. [CrossRef]

77. Mauthner, F.; Hubmann, M.; Brunner, C.; Fink, C. Manufacture of malt and beer with low temperature solar process heat. Energy Procedia 2014, 48, 1188-1193. [CrossRef]

78. Bühler, F.; Van Nguyen, T.; Elmegaard, B.; Modi, A. Process and Economic Optimisation of a Milk Processing Plant with Solar Thermal Energy. Comput. Aided Chem. Eng. 2016, 38, 1347-1352. [CrossRef]

79. Anastasovski, A. Improvement of energy efficiency in ethanol production supported with solar thermal energy-A case study. $J$ Clean. Prod. 2020, 278, 123476. [CrossRef] 
80. Vargas-Bautista, J.P.; García-Cuéllar, A.J.; Pérez-García, S.L.; Rivera-Solorio, C.I. Transient simulation of a solar heating system for a small-scale ethanol-water distillation plant: Thermal, environmental and economic performance. Energy Convers. Manag. 2017, 134, 347-360. [CrossRef]

81. Winterscheid, C.; Dalenbäck, J.O.; Holler, S. Integration of solar thermal systems in existing district heating systems. Energy 2017, 137, 579-585. [CrossRef]

82. Guillaume, M.; Wagner, G.; Jobard, X.; Eicher, S.; Citherlet, S. Solar thermal systems for the swiss pharmaceutical industry sector. In Proceedings of the IEA SHC International Conference on Solar Heating and Cooling for Buildings and Industry 2019, Santiago, Chile, 4-7 November 2019; pp. 550-559. [CrossRef]

83. Frey, P.; Fischer, S.; Drück, H.; Jakob, K. Monitoring Results of a Solar Process Heat System Installed at a Textile Company in Southern Germany. Energy Procedia 2015, 70, 615-620. [CrossRef]

84. Lima, T.P.; Dutra, J.C.C.; Primo, A.R.M.; Rohatgi, J.; Ochoa, A.A.V. Solar water heating for a hospital laundry: A case study. Sol. Energy 2015, 122, 737-748. [CrossRef]

85. Murray, C.; Quiñones, G.; Cortés, F.; Escobar, R.; Cardemil, J.M. Solar Assisted Absorption Machine for the Fermentation Cooling and Maceration Heating Processes in the Winemaking Industry. Energy Procedia 2016, 91, 805-814. [CrossRef]

86. Berger, M.; Mokhtar, M.; Zahler, C.; Al-Najami, M.M.R.; Krüger, D.; Hennecke, K. Solar process steam for a pharmaceutical company in Jordan. AIP Conf. Proc. 2016, 1734, 100001. [CrossRef]

87. Pathak, A.; Deshpande, K.; Jadkar, S. Application of Solar Thermal Energy for Medium Temperature Heating in Automobile Industry. IRA-Int. J. Technol. Eng. 2017, 7, 19. [CrossRef]

88. Bolognese, M.; Viesi, D.; Bartali, R.; Crema, L. Modeling study for low-carbon industrial processes integrating solar thermal technologies. A case study in the Italian Alps: The Felicetti Pasta Factory. Sol. Energy 2020, 208, 548-558. [CrossRef]

89. Crespo, A.; Barreneche, C.; Ibarra, M.; Platzer, W. Latent thermal energy storage for solar process heat applications at medium-high temperatures-A review. Sol. Energy 2019, 192, 3-34. [CrossRef]

90. Lauterbach, C.; Schmitt, B.; Vajen, K. System analysis of a low-temperature solar process heat system. Sol. Energy 2014, 101, 117-130. [CrossRef]

91. Carnevale, E.A.; Ferrari, L.; Paganelli, S. Investigation on the feasibility of integration of high temperature solar energy in a textile factory. Renew. Energy 2011, 36, 3517-3529. [CrossRef] 